Portland State University

PDXScholar

1974

\title{
Sharing information about the child with adoptive parents
}

\author{
Barbara Ashmun \\ Portland State University \\ Beverly McKinney Erickson \\ Portland State University \\ Bente Roberts Parker \\ Portland State University
}

Follow this and additional works at: https://pdxscholar.library.pdx.edu/open_access_etds

Part of the Social Work Commons

Let us know how access to this document benefits you.

\section{Recommended Citation}

Ashmun, Barbara; Erickson, Beverly McKinney; and Parker, Bente Roberts, "Sharing information about the child with adoptive parents" (1974). Dissertations and Theses. Paper 1709.

https://doi.org/10.15760/etd.1708

This Thesis is brought to you for free and open access. It has been accepted for inclusion in Dissertations and Theses by an authorized administrator of PDXScholar. Please contact us if we can make this document more accessible: pdxscholar@pdx.edu. 
SHARING INEORMATION ABOUT THE CHILD

WITH ADOPTIVE PARENTS

\author{
by \\ BARBARA ASHMUN \\ BEVERLY MCKINNEY ERICKSON \\ BENTE ROBERTS PARKER
}

Portland State University

Regional Research Institute in

Social and Rehabilitation Services

1974 
AN ABSTRACT OF

SHARING INFORMATION ABOUT THE CHILD

WITH ADOPTIVE PARENTS

by

\author{
Barbara Ashmun \\ Beverly McKinney Erickson \\ Bente Roberts Parker
}

The study examined differences in the adoption

process between successful and unsuccessful adoptions. The focus of the study was on how much information the parents received about the child prior to placement and on related aspects of the process by which a child is placed in an adoptive home. All information for this study was gathered from the records kept on each child who is placed.

The procedure used was to examine the records of successful and unsuccessful adoptions in three stages. First, an assessment was made of amount and type of information available in the records. It was found that only a scanty amount of information about the actual placement process, concerning the period just prior to the child actually staying in the home of the adoptive couple, was recorded. Second, a pretest of the data collection on key variables was undertaken. It was found that it was possible to separate positive and negative types of information in both recorded and conveyed information. Third, seven successful and seven unsuccessful cases from the year 1971-72 were examined for the variables chosen, namely negative and positive information 
in the record and negative and positive information conveyed. Each record was searched, the variables rated, and ratings were coded.

Results showed no difference between successful and unsuccessful adoptions, in the amounts of either positive or negative information in the record. However, there was more positive information conveyed in successful cases than in unsuccessful cases; despite the small sample this was statistically significant at the 1 percent level by Fisher exact probability. There was also a tendency toward greater conveyance of negative information in successful cases than in unsuccessful ones.

One hypothesis formulated as a result of this study is that the identity formation of the older adoptive child is closely related to the adoptive parents' knowledge of the child's background. If an adequate amount of information about the child and his background is conveyed to the adoptive parents, they are then able to help the child become part of a new family. Thus, the more information about the child and his background is conveyed, the more likely the adoption is to succeed.

A review of the literature covered two areas, comparative practices regarding conveyance of information in the adoption process and the role played by information in the developmental tasks of the adopted child, particularly in identity formation. 
Approved by Arthur C. Emlen, Professor

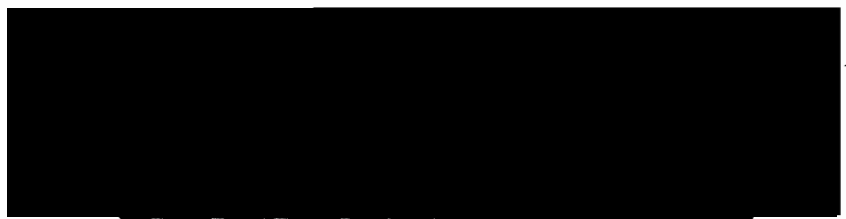




\section{PREFACE}

Any use of the pronoun, he, unless referring to a specific person, refers to women and men equaliy. 


\section{ACKNOWLEDGEMENTS}

We would like to acknowledge and thank those people who have assisted us in this endeavor.

We have especially appreciated the help and instruction of Arthur Emlen, research advisor, who has consistently encouraged us throughout our work.

We thank Barbara Davis, Supervisor of Adoptions for Children's Services for the State of oregon, for her openness in sharing her own experiences as an adoption supervisor. In addition to her being available to us as a resource person, she has generously provided us with records, staff time and a comfortable work space.

We also appreciated Charlotte Donaldson, social worker at Cedar Hills Psychiatric Hospital; for her careful reading of our study and her constructive suggestions, several of which we have incorporated in our study. Special thanks go to Ray Ashmun for securing our research data and original drafts of the practicum study in the safe recesses of a bank vault, to Robert Erickson for his emotional support and unlimited patience and to John Parker for cooperating by letting Bente do her own thing.

We have enjoyed the competence and gracious attitude of our typist, Carleen McAlpin. 
TABLE OF CONTENTS

PAGE

PREFACE ..................

ACKNOWLEDGMENTS . . . . . . . . . . . . . IV

LIST OF TABLES. . . . . . . . . . . . . . . vii

LIST OF FIGURES . . . . . . . . . . . . . . . vii

CHAPTER

I INTRODUCTION . . . . . . . . . . . 1

The Problem . . . . . . . . 1

The Process of Adoption . . . . 1

Definitions . . . . . . . 4

Summary of Study. . . . . . . 5A

Limitations . . . . . . . 5B

II REVIEW OF THE LITERATURE . . . . . . . 5C

Comparative Practices Regarding

the Conveyance of Information.

Identity Formation in Natural and Adopted Children. . . . . . .

III METHODOLOGY. . . . . . . . . . 19A

Summary of Method . . . . . . 19A

Stage 1: Assessment of Recorded Information Available on the Adoption Process. . . . . . .

Stage 2: Pretest of Data Collection on Key Variables . . . . .

Stage 3: The Final study ....

The Ratings . . . . . . . . 
Comparison of Successful and Unsuccessful Cases with Regard to Amounts of Information Recorded and Conveyed

Disparity Between Recorded and Conveyed Information . . . . .

A Closer Look at Amount of Recorded Information. . . . . . . . . .

A Closer Look at Conveyed Information . . . . . . . . . . .

$\checkmark$ CONCLUSIONS, IMPIICATIONS AND RECOMMEN-

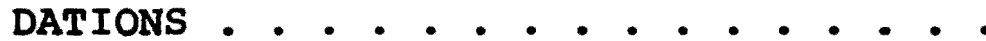

Conclusions. . . . . . . . . .

Implications . . . . . . . .

Recommendations for Practice...

42

Recommendations for Future Research 


\section{IIST OF TABLES}

TABLE

PAGE

1 Amount of Positive Information in the Record

2 Amount of Negative Information in the Record

3 Amount of Positive Information Conveyed . 45

4 Amount of Negative Information Conveyed . -

5 Items of Recorded Information in Successful and Unsuccessful Adoptions . . . . . 49

I Amount of Positive Information Recorded..

II Amount of Negative Information Recorded . .

III Amount of Positive Information Conveyed . .

IV Amount of Negative Information Conveyed . 


\section{IIST OF FIGURES}

FIGURE

PAGE

1 Gaps Between Recorded and Conveyed

Information . . . . . . . . .

47 


\section{CHAPTER I}

\section{INTRODUCTION}

\section{The Problem}

This study was designed to examine the differences between successful and unsuccessful adoptions in the placement of children between the ages of five and eight. Concern was felt about the number of unsuccessful adoptions in the past, and the study was undertaken with the hope of learning about the factors leading to unsuccessful adoptions in order to reduce their number in the future. Thirty-four children between the ages of five and eight felt the impact of unsuccessful adoptions in the years 1964 through 1973 in Oregon, according to the records of Children's Services Division. Statistically, 11 percent of adoptions in 1964 through 1971 and 14 percent of adoptions in 1971-72 were unsuccessful. of course there is no way to measure the traumatic effects of unsuccessful adoption on these thirty-four individuals. Concern for these painful effects sparked interest in the study which follows.

The Process of Adoption

Before the child can be considered for adoption he must be in permanent custody of the Children's Services 
Division. Both parents must have voluntarily surrendered their parental rights or had their rights terminated by court order and the child permanently committed to CSD (ORS 419.527). The Children's Services Division then assumes responsibilities of guardianship with authority to plan adoption. The local county CSD children's workers are delegated the responsibility of providing foster care and casework service for the child pending adoptive placement. Selection and study of adoptive applicants and placement of the child in the adoptive home is the responsibility of specialized adoption workers. The Central Administrative office of CSD performs functions of supervision and coordination. Specifically, since the child's county of residence and the adoptive parents' county of residence usually differ, the Central Administrative office of CSD assumes final responsibility for matching a child with a family. This is done through the State Adoption Committee, consisting of a state Director in charge of agency adoption programs and two county child welfare supervisors. The placement responsibility rests with the adoption committee. 1 During the period of foster care the child is supervised by a children's caseworker who decides whether a child is ready for adoption and prepares the child for adoption. Independent of this process, the adoption worker is studying prospective adoptive parents' homes and evaluating their potential to meet requirements of the 
state for adoptive homes. Records are kept by the children's caseworker concerning the child, his background and adjustment to foster care, and records are kept by the adoption worker of home studies of potential adoptive couples. The Committee is the central clearing house for matching results of these two studies and matching the appropriate child to a suitable family. After this process, the adoption worker whose home is selected returns to the adoptive family to tell them of the child selected for them, without necessarily having seen the child. If the family feels the child sounds right for them, the adoption worker and the child's worker make arrangements for child and family to meet.

The basic information that is to be presented to the prospective adoptive couple before it is decided whether the couple wants to meet with the child includes age, race nationality, siblings of child, health problems, grade in school, and the child's personality and behavior. ${ }^{2}$ It is specified that the child and couple always meet in a neutral setting, that the adoptive couple never meet with the foster parents, and that time be spent away from each other between meetings to give the family a chance to sort out their feelings and be sure of their true response to the child. The child, too, needs time to assimilate what is happening to him. A gradual approach, consisting of short meetings, day meetings and weekend visits, is advocated for use before actual placement. ${ }^{3}$ 
The kind of information that should be given to the adoptive couple once they have met the child is specified as well: "Facts should be limited to those which will help them to better understand the child and his specific needs and enable them to answer questions about his identity and background constructively." 4 Other areas include medical information, such as past illnesses, remedial care and any handicapping conditions, as well as psychiatric information, such as description of personality, recommended and ways of hanaling the child, special interests, aptitudes, and intellectual attainment (but never definite IQ scores). ${ }^{5}$ Information about the natural parents is to be given constructively, which means that no information on their antisocial behavior is to be shared unless the child already knows about it. If the child has no knowledge about adverse home conditions, only positive factors should be given unless such information may be needed by adoptive parents to better understand this child. Since this study deals with older children who might have knowledge about their former home and conditions there, this seems to be an area of importance. How much the child remembers, and how much he is willing to share with his caseworker will affect the picture.

Selected information on mental illness and mental retardation of natural parents for the purpose of having adoptive applicants decide whether to accept the child, and 
to alert them to tendencies that might influence his

behavior should be shared. When a child is finally placed, immunization records, school transcript and surname are given to the adoptive parents. No other papers are given or shown to the adoptive parents. 6

The children's caseworker who has been working with the child makes the final decision when the child is ready to return home with the adoptive family, and deals with that first interaction between the child and his adoptive parents. This worker all along has been preparing the child for what is happening to him and why. After this initial transfer, the adoption worker continues with the child and family during the supervisory period, which lasts from six months to one year and the children's caseworker leaves the picture entirely. The adoption worker is there to help child and family with adjustment problems which may arise during this sensitive period while they are developing the ties and relationship necessary for them to become a real family.

\section{Definitions}

The following terms recur in the study and are used to mean the following:

Successful Adoption: Placement of the child in an adoptive home that becomes permanent and is legally completed by a decree of adoption. 
Unsuccessful Adoption: Placement of the child in an adoptive home that fails to become permanent and results instead in removal of the child from that home. Children's Caseworker: Caseworker who is responsible for cases which are related to all aspects of children's problems, including foster care, child abuse, delinquent. children, adolescent problems.

Adoption Worker: Caseworker who is a specialist in all areas of adoption, including recruitment of adoptive homes, home studies of adoptive applicants, participation in adoption committee meetings, cooperative participation with the children's caseworker in the placement process, work with adoptive parents and child after placement to assist with the child's settling into the family.

Recorded Information: Information in the record about the child, and his background.

Conveyed Information: What the record shows the adoptive couple was told about the child and his background.

\section{Summary of study}

The study concerns itself with the process by which the child is placed in an adoptive home and more specifically with how much information the parents received about the child prior to placement. All information for this study was gathered from the record that is kept on each child who is placed. 
This exploratory study shows that there are important differences in the amount and kind of information conveyed to the adoptive couple by the-adoptive worker. In successful adoptions more positive as well as negative information was conveyed than in unsuccessful adoptions. It was found, however, that the communication loss was not due to a gap in information available. The records showed no discernible differences in amount and kind of recorded information in successful and unsuccessful cases.

The hypothesis formulated as a result of this study holds that the identity formation of the older adoptive child is closely tied to the adoptive parents' knowledge of the child's earlier life experiences and the degree that they are comfortable with this information. These factors strongly influence the parents' ability to help the child become part of a new family and the child's subsequent acceptance of the family. This can only be accomplished if an adequate amount of information is conveyed to the adoptive couple about the child and his background.

\section{Limitations}

This is an exploratory study of semen successful and seven unsuccessful adoptions. The purpose is to discover and generate hypotheses about the adoption process. Hopefully future studies will test these hypotheses so that they may be applied in practice, namely Aelivery of 
service to adoptive parents. However, hypothesis testing is not within the scope of this study.

Due to the iimitations of time, financial resources and the small number of researchers involved in this study, it was decided to limit the data studied to case records of adoptions in the files of the children's Services Division. All results then are limited by the quality and quantity of the material recorded, for it is solely on these data and inferences drawn from these data, that the study is based. 
CHAPTER II

REVIEW OF THE LITERATURE

The two areas of greatest concern to the researchers as the study developed were 1) the quality and quantity of information conveyed to the potential adoptive parents and 2) the developmental tasks of the adopted child, especially identity formation. These two themes seemed to be the most significant ones regarding the adoptive couple and the adopted child as each was involvea in the adoption process. A survey of the literature concerning these two areas of interest follows.

Comparative Practices Regarding the Conveyance of Information

The Child Welfare League of America has specific guidelines on what information to give to a prospective adoptive couple about their child. "Information should be given about child and his natural family that will help them (adoptive couple) to understand the child and his special needs or problems.... and to answer questions which he may later ask about himself, his original parents and background." 7

This is a very general guide leaving a lot of leeway to the worker as to the suitability of known information to be shared. However the guidelines become more specific when the list of information to be shared goes on to 
include developmental history, medical data, personality and temperament, psychological examination, family background with emphasis on their strengths and specific hereditary conditions. 8

It is not made clear how complete the sharing of such things as psychological information should be.

One area that the league is more specific about concerns the process of relinquishment from natural parents. In this area it is recommended that the adoptive couple be given positive interpretations of why the biological parents relinquished the child. The writer(s) suggests that giving up the child is to be seen as a positive step taken in the child's interest rather than as a rejection. Helping the adoptive couple with this relinquishment will especially benefit an older child who might remember his parents. 9 Another way a worker can help the adoptive couple feel more comfortable about a child's background is to evaluate an adoptive couple's attitudes toward unmarried mothers and children born out of wedlock. 10

These guidelines imply that if the adoptive couple learn to accept their child's background it will be more natural for them to help the child accept his ties to the past.

It is of interest to note that there seems to be little agreement on what information is shared and what is helpful to be shared and that views are constantly changing. 
At an Adoption Conference in 1951 it was agreed upon that a caseworker must know as much as possible about the child to be placed in order to select "out of his knowledge the pertinent facts helpful to the adoptive parents in helping the child integrate his background."ll However the caseworker is only to tell about the natural parents' own social situation as it led to giving up the child for adoption. ${ }^{12}$ Here it becomes clear that it is up to the adoptive worker to discriminate what is pertinent and what is not.

Four years later at the Adoption Conference in 1955 the majority of workers agreed that nothing should be told the adoptive couple regarding the child's background, but some workers still felt that selection of pertinent facts that would be helpful to the adoptive parents and the child needed to be shared. ${ }^{13}$ There was unanimous agreement that it would be unsound to give out any information about a condition around which there is common prejudice, but what actually constituted such information could not be agreed upon. 14 Here again, it becomes clear that it is up to the discretion and judgment of the worker what he shares and what he chooses to keep to himself.

One study was done in 1954 in 254 agencies dealing with adoptions. Here it was found that half of the agencies would give complete information on background and half of the agencies would not. As the researchers probed further it 
was found that complete background information generally was qualified to mean only selected material or facts that could become pertinent for the welfare of the child and his adoptive parents. ${ }^{15}$ So this study again shows little agreement on what is actually shared.

In England there is the same disagreement on how much information the adoptive applicants should have about the child, ranging from nothing to full information.

In England it is the subjective view that prevails that the worker has considerable discretion in his choice about sharing information. ${ }^{16}$ There is great uncertainty about what is suitable to convey.

During research done in England about information shared it was found that the records used for the research were generally inadequate in disclosing what information was shared. 17 In addition, it was noted that the frank staff worker gets lots of criticism about sharing potentially disturbing material which could be interpreted as a burden rather than a plank to a stable relationship between the child and parents. 18

Agencies which gave only few details were also criticized for not being responsible toward the adoptive couple. 19

It seems clear that giving of information to the adoptive couple is one of the less well thought out aspects of the adoption process. One reason for this is that no 
objective data exists in regard to what the adoptive couple wants to know about background, 20 and no research has been done on what children have wanted to know from the adoptive parents about the adoption and what took place before the adoption. $^{21}$

There are many different opinions of what to share about the child and his background. In England a study was done to shed some light on what adoptive couples later found out about the information given to them at the time of adoption. 22

Those able to identify with the child's natural parents felt this brought them closer to the adopted child. This implies not only giving of information about background but also a process of working through of what the knowledge means to them. 23

It was also found that if the background information was not seen as very different from that of the adoptive couple they attained some assurance in knowing specifics. Specific data about the natural parents' age, appearance, job and interests were valued as well as other facts considered socially acceptable. ${ }^{24}$

The few adoptive couples who had been told about a history of mental illness and abnormalities were very anxious. Sharing of potentially threatening details was sometimes reinterpreted by the adoptive couple to fit their needs. ${ }^{25}$ The area of illegitimacy was a cause of real 
concern. Adoptive parents feared tendencies toward promiscuity and were afraid that disclosure of illegitimacy would lead the child into unmarried parenthood. 26

With too little information shared the outcome tended to be speculation and discomfort about these speculations. ${ }^{27}$ This study gives us some ideas about how important sharing both factual information and the meaning of this information is for the adoptive couple.

Lela costin comes up with three reasons it is necessary to share information with the adoptive couple.

1. To help prospective parents make up their mind about whether to accept the child.

2. To help secure their relationship with the child.

3. To satisfy the child's future wish to know about his background by helping the adoptive couple to be able to give such information in a constructive manner. 28

Adopting an older child is not the same as adopting a baby, in terms of the emotional content for both the parents and the child. "Adopting an older child is a process whereby individuals already equipped with consciousness, memories and large amount of life experiences link their lives together." 29 Since this is the case, different ways of placing the child have to be considered. According to Kadushin it is probable that most couples would originally have wanted a young child. So even though 
an older child ultimately becomes acceptable, it would not have been their first preference. This is noted in several research studies about adoption of older children. ${ }^{30}$

The process of change in preference is gradual and the worker can be of great help in working through with the applicants that the realities of the situation made a shift in preference necessary. For example, he may emphasize that older children are nore readily available for adoption and that the age of the applicant suggest an older child. ${ }^{31}$ The home study and gradual shift in preference for an older child set the tone for the openness that is necessary for placement and post placement supervision. ${ }^{32}$

As the child is older and has memories it is fruitless to withhold information about background as the child can reveal them. ${ }^{33}$

Anne Leatherman feels the worker must describe the child, his medical and social history. She finds it best to emphasize positives in the child's background and the effect specific situations have had and are likely to have. ${ }^{34}$

Some sympathetic understanding of the reasons that the child's natural parents cannot carry responsibility for the child should also be explored. Here it is necessary to help the adoptive parents examine their own feelings about parents who are immature, inadequate and who neglect their children, so the adoptive couple can come to grips with the negatives of the child's background. ${ }^{35}$ 
One more way the worker can help the parents deal with information conveyed is to encourage them to let the child talk about his memories and have them respond with no anxiety to his reminiscences. This can be done by helping the parents remember their own childhood feelings in new situations and at times of separation. ${ }^{36}$

Thus part of the home study is to prepare the adoptive couple to deal with general and specific problems they are likely to encounter in adopting an older child. This helps them accept the idea of an older child. It includes such areas as discipline, and the adoptive parents' feelings of imposing and enforcing limits on the child, the child's attachments to previous family groups, reactions of significant others to the adoption of an older child. 37

Here it can be added that Velma Bell sees great value in preservation of the child's relationship with certain selected members of the child's natural family. The reason for this suggestion is that it helps the adoptive family accept not only the child, but also that which belongs to him before ties are made to the adoptive family. 38 If the home study and placement process has been an open communication it will be easier for the family to seek help later on from the worker with any camplications, as seeking help is not seen as a failure but as an indication of good parenting. 39 
Kadushin sums up what a worker's responsibility has to be if he is to effectively carry out the responsibility of helping the adoptive couple accept an older child. "He needs to be knowledgable about the stress this new role imposes, the nature of the possible desirability and satisfaction that might be encountered. He needs to be more of an expert than the potential couple and the profession must provide the worker with such knowledge." 40 In giving of information about the child the worker needs to stick to the social work principles of individualization and participation. 41

This means there can be no set routine both on what information is shared and how it is shared. Sharing has to be appropriate for both the prospective parents and the child. For example, in describing the child it is helpful to keep to the facts and leave out a worker's subjective views such as cute or bowlegged as parents need to see the child free of the expectations and opinions of the worker. This advice also includes not going overboard in enthusiasm and approval of the child in order to let the parents' expectations and feelings have freedom. 42

Under individualization specific details of an older child's background, and earlier experiences need to be given with careful interpretation of early problems of adjustment so the adoptive parents can meet problems with understanding. They need to be familiar with the background 
of fears and anxieties and how the child acts out these feelings in order to be of maximum help in aiding the child to gain security.

In giving background information such as occupation, nationality, education and appearance of parents, the worker first has to examine these facts for accuracy, pertinence and meaning to the adoptive couple, not just deliver facts as routine information. 43

The worker has to remain alert to unspoken anxiety about background and be prepared to discuss areas such as anxiety in regard to lack of information about the natural father. Nothing is gained by not bringing anxiety out in the open. 44

The principle of participation also needs to be adhered to as it will result in greater understanding and integration of material presented. 45 If participation is successful before placement it will reinforce sharing of feelings on the part of the adoptive couple and their child.

Some resistance can be expected here as 1) discussion of the natural parents points out that the couple needs to take someone elses child as their own, 2) parents have a stake in withholding feelings that they feel might endanger their chances of getting the child, and 3) the worker might feel uncomfortable about sharing information because of limited knowledge and many unknown and different opinions about giving information. 46 
The worker has to sort out his own feelings about illegitimacy, hereditary conditions, neglectful parents, mixed racial children, etc. otherwise he may be unable to create the atmosphere that supports and encourages prospective couples to deal with their own feelings and anxieties. 47

It cannot be emphasized enough that the way history giving interviews are conducted set the stage for the future. At some point in time the child will wish to know about his background. Whether the child can identify with the positives about his natural parents depends upon the quality of the relationship between the adoptive parents and child, and the parents' attitudes toward his background. It is the adoptive parents who can give the child a sense of worth in relation to his origin. 48

"Thus social work has both the opportunity and responsibility to help in the situation that may come up years later when the child brings up the questions of his adoptive parents.

Even if they have no adequate specific data it is important for them to be able to allow and enable their child to bring the needs for questions out in the open in an understanding atmosphere. The child needs to have a satisfying image of his own natural parents if he is to attain the stage of emotional maturity that will help him grow up and incorporate this into his identity of his 'self'." 
Identity Formation in Natural and Adopted Children

In considering the matter of identity and its formation as it occurs in the adopted child, the concept of identity may be seen as having three parts: personal identity, social identity and ego-identity. ${ }^{49}$ Goffman defines personal identity as those unique aspects of the individual which differentiate him from all others. The unique aspects include the physical image, as well as facts about him as an individual which do not hold as a combination for any other human being. Thus, these personal characteristics constitute a unique stimulus to the social encounter and generate evaluation and expectations.

According to Goffman, personal identity serves to differentiate an individual from all other individuals-his social identity establishes to what extent he is like some or all others in the social set-up. Thus, a person's social identity is composed of attributes and categories imposed on an individual by his society. The term "adopted," for example, in our own society indicates that the adopted child is different from the child we call "natural." 50 The ego-identity, as discussed by Goffman, is a person's subjective sense of his own situation and his continuity and character resulting from the integration of his personal and social life experiences.

At this point, each of these three parts of identity formation as they occur in development in the natural child 
and the additional tasks required of the adopted child in the formation of identity will be explored. 51

Regarding the personal aspect of identity formation, the tasks of the natural and adopted child are essentially the same in that both must come to terms with a given set of physical and personal characteristics which have nothing to do with whether or not a child is natural born or adopted.

As mentioned before the social identity of an individual establishes to what extent he is like some or all others in the social system. It is through the acquisition of social identity that an individual is categorized. Social identity can be either positive or negative. In our society the child born to natural biological parents is seen as "normal" and the term "adopted" used to refer to a child not living with his biological parents immediately signals that there is socially an important difference between the child who is "normal" and one that is "adopted." The author Joseph Ansfield in his book regarding adoption asserts that being an adopted child in our society is still to be stigmatized. He believes that just as the handicapped child is stigmatized so is the adopted child. 52

A very important additional task that goes with being adopted in our society is that of coming to terms with society's disapproval of the matter of illegitimacy, or the neglect and rejection by natural parents, which are 
often associated with adoption. Jean Seglow, author of Growing Up Adopted, says "...although social disapproval of illegitimacy may be lessening this in no way detracts from its potency. As long as this attitude exists in the community, the adopted child will feel discriminated against." 53

Regarding ego-identity formation, five of Erikson's eight stages in ego-identity formation seem vital to a discussion of identity development for the natural and adopted child. In an exploration of each stage, the natural process and a discussion of implications in terms of the additional tasks posed for the adopted child in his identity formation will be explored. 54

Erikson describes the first step in ego-identity formation as that of basic trust which he defines as an essential trustfulness of others as well as a basic sense of one's own trustworthiness. he says that this is a pervasive attitude toward oneself and the world derived from experiences in the first year of life. ${ }^{55}$ Mothers create a sense of trust in their children by the kind of care which combines sensitivity to the baby's individual needs and by their personal trustworthiness. This establishes the basis for the sense of identity. In the special situation of the adopted child there is a real question about whether or not the maternal care received by the child prior to being adopted has been adequate. 
Most probably the natural mother would be emotionally upset and possibly in conflict over whether or not to release her child for adoption. Under these circumstances there may be reason to doubt that the nother herself has attained the sense of her own personal trustworthiness in order to pass that on to her child in the form of adequate physical and emotional care. Thus, it would appear reasonable to question whether or not the child who is voluntarily or through court action placed for adoption (perhaps depending on the age at time of placement) possesses a sufficient sense of trust necessary to the development of a sense of autonomy.

In addition to the question of the quality of maternal care and whether or not the mother is able to transmit to the infant a sense of basic trust, there is the important issue of separation and placement with which each adopted child, whether a baby at the time or an older youngster, must come to terms. Erikson states that a drastic loss of accustomed mother love without proper substitution at this time can lead, under otherwise aggravating conditions, to acute infantile depression or to a mild but chronic state of mourning which may give a depressive undertone to the remainder of one's life. ${ }^{56}$

Ner Littner feels as Erikson does, that separation from the natural parent and placement away from the natural parents has serious implications. This may indeed be the 
most psychologically difficult additional task that an adopted child must face and master in order to attain an adequate sense of identity. No matter what the age is at separation and placement the psychological process that he must go through is the same. Within this process the child is confronted with a series of important psychological tasks. 57 In the course of being separated from natural parents the child experiences much pain and anger and he must therefore do certain things in order to come to terms with these feelings. In order for the child to gain mastery of these feelings he must 1) master the feelings aroused by the separation from his natural parents, 2) master the feelings initially stirred up by being placed with new parent figures, 3) master the feelings of fear that go with any incident of separation from these new parents, and 4) master the feelings of fear regarding psychological closeness to new parents. 58 Furthermore, most children react to separation from natural parents with fear and anxiety. The child feels abandoned and helpless and feels anger at the parent he believes has deserted him. The child tries to deny his helplessness by taking on the opposite feeling of responsibility for the abandonment, and blames himself for the events leading to the separation. Littner believes the child seeks a specific badness within hemself on which to blame the events of separation, and usually selects the task he is 
attempting to master at that particular stage of his physical and emotional development that is coincident in time with the separation. For example, he may have a feeling of failure anä shame about not learning how to walk, or to control bowels, or he may have a feeling of badness associated with some unacceptable impulse, such as anger at mother. 59 Another feeling that goes with separation is fear of punishment which might be in the form of the complete desertion or death of a parent, fear of personal body mutilation, or fear of his own death. The second stage of normal ego-identity development as described by Erikson is that of the sense of autonomy which is the feeling that it is all right to be oneself and to become what other people trust one will become. Comparative studies in child training have demonstrated that the kind and degree of a sense of autonomy which parents are able to grant their children depends on the dignity and sense of personal independence they derive from their own lives. The sense of trust is a reflection of the parents' dignity as autonomous beings. 60 The important thing to take out of this stage is the very courage to be an independent individual who can choose and guide his own future--an important part of eventual identity formation. The implications of this stage for adopted children might be very similar to those of the trust building stage as those relate to the possible immaturity 
of the natural parents of children that are released for adoption who themselves may lack a real sense of independence to choose and to guide their own futures, thereby being unable to give this sense of independence to their offspring. If the child is older at the time he or she is released for adoption it is more likely that he did not receive a sense of independence from the people who were his natural parents. Another factor which might be a problem for the adopted child already in adoptive placement at this stage in development is suggested by Kirk, who states that if the adoptive parents have not themselves resolved important feelings around such issues as their inability to bear their own biological children, they will be unable to help the child deal with being adopted, part of his social identity. 61

Erikson's third stage is the development of a sense of initiative as a basis for a realistic sense of ambition and purpose. The indispensible contribution of this stage to later identity development is that of freeing the child's initiative and sense of purpose for adult functioning which promises fulfillment of a whole range of capacities. 62 The following stage involves the sense of industry or the sense of being able to make, things and make them well and even perfectly. 63 Erikson describes a common danger in normal development as the development of an estrangement from oneself and from his tasks which he lables as the sense 
of inferiority. This may be caused by the insufficient solution of the preceding conflict--the child may still want to be at home with his mother more than he wants to learn, for example. His early home life may not have prepared him to be ready to learn and he may still be concerned about resolving some of the earlier developmental problems of earlier stages. The implications for the adopted child would seem to be that there is a greater chance than normal that his early life experiences may not have provided him with circumstances conducive to his successfully completing earlier stages of ego-identity development.

Another important task for the adopted child occurs when he goes to school and encounters other children with ideas and social prejudices about adoption. These experiences may affect his self concept and interfere with his learning.

Erikson stresses that socially this is a most decisive stage because the sense of industry involves doing things beside and with others. ${ }^{64}$ At this time when society becomes so important and the issue of parental background becomes so important the adopted child appears to have one or two major additional tasks to master that the child living with natural parents does not have to face. Those are 1) to come to terms with what it means to be adopted and 2) to come to terms with what it means to be personally 
associated with the terms "illegitimate" and "out-of-wedlock." Kirk, in his book, Shared Fate, states that beginning at" the age of six and at the time the child is entering school there is a wide expansion in the child's conceptual horizon. During this period there is the most readiness to take in much of what he really needs to know for his understanding about his being adopted. This is the time when school and peer influences begin to replace those of the family. ${ }^{65}$ Pringle believes that part of the process of coming to terms with being adopted is coming to terms with the knowledge that one differs biologically from the adopted parents. Pringle calls this "geneological bewilderment" meaning curiosity about the biological parents. 66 This curiosity occurs for the child following the adoptive parents having told him that he is adopted and thus is different from themselves biologically. 67 Along with the issue of "geneological bewilderment" the child will ask and have to deal with the questions of why he was given up. He will undoubtedly feel the need to make inquiries and the adoptive pair needs to be able to give him information about the events of his adoption and be psychologically supportive so that he can master his sense of the situation. ${ }^{68}$

An additional task that arises for the older adopted child is that of coming to terms psychologically with at least two sets of parental messages that have to do with ways of doing things. Kadushin says that the adoptive 
home offers living experiences which teach new ways of relating to people and of seeing the self which challenge the child's old ways of relating to people and seeing the self. Often when a child is adopted after being removed from the home of his parents, he is placed in a home of different, higher social standing. While he may have originally received messages in his early environment of not being acceptable socially, he may now be regarded as acceptable. 69

So it is at Erikson's age of industry when the adopted child begins to spend much of his time with his age mates in the school and in the neighborhood and is no longer protected by his adoptive parents that he needs a sense of competency about the facts of his adoption and about adoption in general and its special cultural meanings in order that he may cope successfully psychologically and socially and thus make a suitable transition to the next stages in the formation of his identity. 
CHAPTER III

METHODOLOGY

Summary of Method

This is an exploratory study with the purpose of discriminating between successful and unsuccessful adoptions. The procedure used was to examine the records of successful and unsuccessful adoptions in three stages. Each stage narrowed the focus of the study to more specific and concrete variables:

\section{Stage 1: An Assessment of Recorded Information} Available on the Adoption Process. The first stage included examination of the records that are kept on each child in order to learn about the amount and type of information available in the records. It was found that only a scanty amount of information about the actual placement process, concerning the period just prior to the child actually staying in the home of the adoptive couple, was recorded.

\section{Stage 2: Pretest of Data Collection on Key Variables.} The period just before tha actual placement became the focus of the second stage of the study. A number of randomly chosen successful and unsuccessful case records were searched for amount of positive and negative information about the child, and positive and negative information conveyed to the adoptive couple. It was found that it was possible to separate positive 
and negative types of information in both recorded and conveyed information.

Stage 3: Final study. In the final study 7 successful and 7 unsuccessful cases, both from year 1971-72, were examined for the variables chosen, namely negative and positive information in the record and negative and positive information conveyed. Each record was searched, the variables rated, and lists compiled about the specific areas designated as variables. Each rating was later coded independently by a different investigator to establish reliability..

Stage 1: Assessment of Recorded Information Available on The Adoption Process

Consideration was given first to variables that might differentiate between successful and unsuccessful adoptions. Most of the variables discussed fell into one of three major categories: 1) those related to the adoptive worker, 2) those related to the child, and 3) those related to the adoptive couple. Variables related to the adoptive worker included number of interviews with adoptive parents, depth of interviews, whether supportive services were provided after placement, worker's ability to help child deal with loss of child caseworker and loss of foster family. Variables related to the child included preparation of child for adoption, and knowledge of the child's background. Variables related to the adoptive parents included expectations of the child, ability to cope with past problems and experience in parenting. 
One final variable related to the adoptive couple was the presence of other children in the family, either previously adopted or previously born natural children, since sometimes other children in the family will resist the adopted chilo's incorporation into the family.

Before a study could be designed to discriminate successful and unsuccessful adoptions, an assessment had to be made of the availability of information in the adoption records. This assessment was undertaken and in the process impressions were gathered about the content and process of the adoptive placement.

Three variables under each category were selected and the records were searched to assess the amount of evidence available in each area. All the records studied on this occasion were of unsuccessful adoptions. A scale ranging from one to four was used, one meaning no information and four indicating the most complete information. The differences between a rating of two, three aná four were not specifically defined since this was a preliminary investigation intended to establish whether the information was available in the records, and whether the authors perceived the amount of information similarly. Intercoder reliability was tested for by each coder independently scoring each variable in the cases. Since this was an extremely time-consuming procedure, each coder began with one separate case and rotated cases when she finished in order to test for intercoder reliability. 
All coders did not each read every case. At this preliminary stage it was felt that such thoroughness was not necessary since the primary task was to become familiar with the kind of information available in the records. The results of this preliminary exploration of several records are found in Appendix A.

To summarize, the data showed that there was consistently full information regarding the child's health, number of placements and adjustment in foster home(s). The same was true of the amount of information regarding the adoptive parents' experience in parenting. The amount of information regarding adoptive parents' expectations was varied and the amount of information regarding the adoptive parents' problem solving ability was relatively low. The amount of information about the worker's ability to assess the adoptive parents was relatively complete. In general, the records showed relatively complete information concerning the child and his background as well as the adoptive parents and their background.

In contrast, consistently scanty information was found regarding preparation of the child for adoption, preparation of the adoptive couple for the specific child, and amount of supportive services from period of placement to adoption or replacement. These last three variables are the ones concerning the actual placement process and the matching of the child to the adoptive family. 
There were other indications that the placement process was an area of weakness. For example, guidelines to adoptive home study and study of the child were made available to the investigators, and the guidelines in this area seemed to have received more attention than the placement process. More important, however, weakness in the area of placement occurs inevitably because of how the process is organized and staffed. The fact that the child's county of residence usually changes with adoption requires a change of caseworker for the child, and is an additional source of difficulty in achieving a transfer of information. In addition, the age range of the children selected for study, five to eight years, makes them harder to place since most adoptive parents prefer infants or younger children. This might lead to glossing over the problems a child might have in order to make him appear more desirable for placement, and contribute to a lack of information conveyed.

To go a step further, a lack of preparation of the parents for the specific child, and a lack of supportive services from the time of placement to the point of adoption would probably make it even more difficult for a family to deal with the differences in the adoptive children and to help the child deal with identity problems that might arise later on. These issues might be significant in differentiating between adoptions that succeed and those that do not. 
As far as intercoder reliability of the variables originally searched for and coded, there was perfect congruence in coding between Researcher A and Researcher B, but Researcher $B$ and Researcher $C$ differed in their coding of the same variables most of the time. This indicated a need to construct precise definitions of variables in order to ensure greater intercoder reliability. This was done during the next stage of the study.

since the placement process was identified as the area of weakness, variables were selected that related to that process, and that would provide a basis for assessing how information flowed through it. Two variables were selected: 1) Amount of information in the record regarding the child and his background, and 2) amount of information in the record regarding the child and his background that was conveyed to the adoptive parents. The records would be searched for data relating to these variables. An adaitional task would be to measure the discrepancy between these two variables. In view of a possible reluctance to convey negative material, each variable was further subdivided into positive and negative components, resulting in a total of four variables: 1) Amount of positive information in the record regarding the child and his background, 2) amount of negative information in the record regarding the child and his background, 3) amount of positive information the in the record regarding the child and his background 
conveyed to adoptive parents, and 4) amount of negative information in the record regarding the child and his background conveyed to adoptive parents.

Positive information about the child and his background includes the child's assets and factors in his background that would be growth inducing. Negative information includes the child's liabilities and factors in his background that could be detrimental to growth. Impressions while reading the records during the first pretest were that these two kinds of information existed in the record and could be differentiated. Initial impressions were that in trying to place these hard-to-place children, negative information about the child and his background was withheld from the adoptive parents. Therefore information recorded and conveyed was separated into positive and negative categories. Furthermore, an even greater discrepancy between negative recorded and conveyed information in unsuccessful cases than in successful cases was hypothesized, since that information would be important for the adoptive parent to know in order to successfully deal with differences and identity problems of their adopted children.

This is not to say that less interest was taken in the positive information. Certainly both positive and negative information are necessary contributing factors toward the child's identity and adjustment in the adoptive home. 
Stage 2: Pretest of Data Collection on Key Variables

In order to test out impressions that the four

variables could be rated reliably from material reported in the records, a small sample of cases was examined. Both successful and unsuccessful cases selected by the agency without any specific random selection method, were included. For each case both positive and negative information in the record regarding the child and his background, were listed, as well as positive and negative information in the record regarding the child and his background conveyed to the adoptive parents. This was an effort to further define the four variables and also to see how much contrast there was between recorded and conveyed information.

A composite picture was made of positive information, drawing on data from all cases. A parallel composite picture of negative information was assembeled. Conveyed information was listed separately for each case since there was so little conveyed.

Under positive information recorded, physical description of the child was found, such as happy, handsome, attractive, charming, physically athletic, natural, charmer, tidy; some health information was found, such as good sleep patterns, normal developmental history, healthy, good eater, no health problems, no physical defects. There was also behavioral description, such as loves dogs, outdoors, books; outgoing, warm, well adjusted in foster home, 
IQ 109, good understanding and preparation for adoption, sense of humor, cooperative, understands he's foster child, relates easily, enthusiastic about adoption, well integrated into foster family, appropriate behavior with men and boys, mature, knows own mother, good in school, affectionate, follows orders, speech improved, behaves. There was background information such as how foster parents dealt with temper tantrums, that child needs home with other children, that child had two good foster homes.

Under negative information recorded data were found about parents, such as mother not married, mother married and divorced, nothing known about father's background, mother arrested, complaints about mother's child care, black father and white mother, mother raised in foster care, mother at Hillcrest for three years, mother's parents divorced, mother leaves home in early adolescence, mother on AFDC when child born, mother disorganized, mother currently working, mother abuses and neglects child, no father named, mother drinks. There also were data about child's living arrangements such as foster care at one month, back to mother at two months, foster care again, ward of court at four months, three foster homes, no case material, beaten, unattended, ragged, poor foster home. There was behavioral information about the child, such as temper tantrums, bed wetting, trouble in school, beyond control, lying, disobeying, sex play, does not respond to 
rewards, not toilet trained at three, sensitive to correction, insecure, speech defects, no progress, worried, flighty. There was health information such as ear problems, constipation, allergy, hospitalized four times for ear problems. This information included data from four cases. Some of the specific points recurred in several of the cases, but for clarity were enumerated only once.

In general, it was felt that an adequate picture of the child's appearance, behavior, health and background could be obtained from the positive and negative information in the record combined.

Since so little information conveyed was found, cases can easily be described separately for these variables. Case \#l mentioned only a previsit which was considered an indication of both positive and negative information conveyed. It was inferred that a previsit gives the adoptive couple some information about the child and since there is no indication of whether it is positive or negative, it is considered to be both. Case \#2, under positive information conveyed, mentions a two-day previsit, and couple has understanding of problems with child. Under negative information conveyed, there is mention of a two-day previsit, older mixed-race boy, culturally deprived, bed wetting, behind in school. Case \#3, under positive information conveyed, has several previsits, and under negative information conveyed, several previsits. For Case \#4 all conveyed 
information was listed under both positive and negative since all the data were very general and could fit in either category. This included meeting with adoptive parents in the worker's office, talk of child's needs, knows about health record, knows how foster parents handle problems, knows names of other children in foster home. Certainly this survey of the records shows that there is much more information recorded than evidence of information conveyed to the adoptive parents. It is also clear that all the variables are present in the record. Enough evidence was found to continue with the full study.

\section{Stage 3: The Final Study}

The Sample. The largest number of unsuccessful adoptions occurred during the year 1971-1972 in the age range of five to eight, and for that reason it was decided to study that year and that age range. This means, more specifically, that the children were five years and zero days to seven years and three hundred sixty-four days at the date of placement in the adoptive home and that placement occurred between July 1, 1971 and June 30, 1972. According to the agency's official statistics there were fifty-one placements that year. Of these, seven were unsuccessful adoptions. Since there were only seven unsuccessful adoptions, a decision was made to study all of those cases and compare them with a random sample of seven successful cases. A random sample was obtained by using a table of 
random numbers to select seven cases from a numbered list of all successful adoptions.

of the children whose adoptions were successful, four were female and three were male. Five of these seven were White, one was Nonwhite, and one was Spanish. of the children whose adoptions were unsuccessful, one was female and six were male. Five of these seven were white, one was Nonwhite, and one was of mixed Nonwhite-Indian and White origin.

The Ratings. The records of all fourteen cases were then examined for information related to the four variables. Each record was examined by only one researcher. For each record a list was made of all data pertaining to each variable. Complete data are found in Appendix B.

In order to code the information for comparison purposes the following four categories were constructed for both positive and negative information in the record regarding the child and his background:

a. No information.

b. Physical description of child and health of child.

c. Background information including data about child's parents and extended family, foster family, and their relationship to child, as well as history of schooling.

d. Behavior of child including developmental history such as when began to walk, talk, sit up, eating habits, sleeping patterns, IQ, as well as child's relationship to significant others, interactions, and habits. 
The following four categories were constructed for both positive and negative information in the record regarding the child and his background conveyed to adoptive parents :

A. No information.

B. Mention of visits prior to placement of child in adoptive home.

C. Background information regarding parents, extended family, foster family and their relationship to child, as well as history of schooling.

D. Behavior, health, and description of child. Behavior includes everything already mentioned in $d$. above.

These categories were used to code each entry under each variable. A scale of one to four was constructed. If only category a or $A$ appeared under a variable, the amount of information was rated 1. If any one category with the exception of a or A appeared, the amount of information was rated 2 . If any two categories with the exception of a or A appeared at least once each, the amount of information was rated 3. If all three categories with the exception of a or $A$ appeared at least once each, the amount of information was rated 4 . Based on these ratings Appendix $\mathrm{C}$ was constructed. 
CHAPTER IV

RESULTS

Comparison of Successful and Unsuccessful Cases With Regard to Amount of Information Recorded and Conveyed

The ratings of each specific record for amount of positive information, amount of negative information, amount of positive information conveyed and amount of negative information conveyed are shown in Appendix $c$.

Four tables were constructed to compare successful and unsuccessful cases with regard to the amount of positive and negative information recorded and conveyed. Complete tables are shown in Appendix D. To emphasize the results of these tables, categories 1 and 2 were collapsed into one category and category 3 and 4 were collapsed into another category. Tables 1 through 4 were constructed, based on these collapsed categories.

Table 1 shows no difference between successful and unsuccessful cases in regard to the amount of positive information in the record. Likewise, Table 2 shows no difference between successful and unsuccessful cases in regard to the amount of negative information. Thus, no matter whether the information was positive or negative, the amount in the record was the same for successful and unsuccessful cases. 
TABLE 1

AMOUNT OF POSITIVE INFORMATION

IN THE RECORD

\begin{tabular}{|l|c|c|}
\hline \multicolumn{2}{c}{ Amount of Information } \\
\hline outcome & low & high \\
\hline successful & 0 & 7 \\
\hline unsuccessful & 0 & 7 \\
\hline
\end{tabular}

low = categories 1,2

n.s. high $=$ categories 3,4

TABLE 2 .

AMOUNT OF NEGATIVE INFORMATION

IN THE RECORD

Amount of Information

\begin{tabular}{|l|c|c|}
\hline outcome & low & high \\
\hline successful & 1 & 6 \\
\hline unsuccessful & 0 & 7
\end{tabular}$\quad \begin{aligned} & \text { low = categories } 1,2 \\
& \text { high = categories } 3,4\end{aligned}$

However; the picture changes dramatically with

respect to conveyed information. Table 3 shows more positive information conveyed in successful cases than in unsuccessful cases. This was statistically significant at the 1 percent level by Fisher exact probability despite the small number of cases involved. Table 4, while not statistically significant, was in the same direction, showing a tendency toward greater conveyance of negative information in successful cases. 
TABLE 3

AMOUNT OF POSITIVE INFORMATION CONVEYED

\begin{tabular}{|l|c|c|}
\hline \multicolumn{2}{c}{ Amount of Information } \\
\hline outcome & low & high \\
\hline successful & 1 & 6 \\
\hline unsuccessful & 7 & 0 \\
\hline
\end{tabular}

low $=$ categories 1,2
high $=$ categories 3,4
p $<.01$ Fisher exact
probability

TABLE 4

AMOUNT OF NEGATIVE INFORMATION CONVEYED

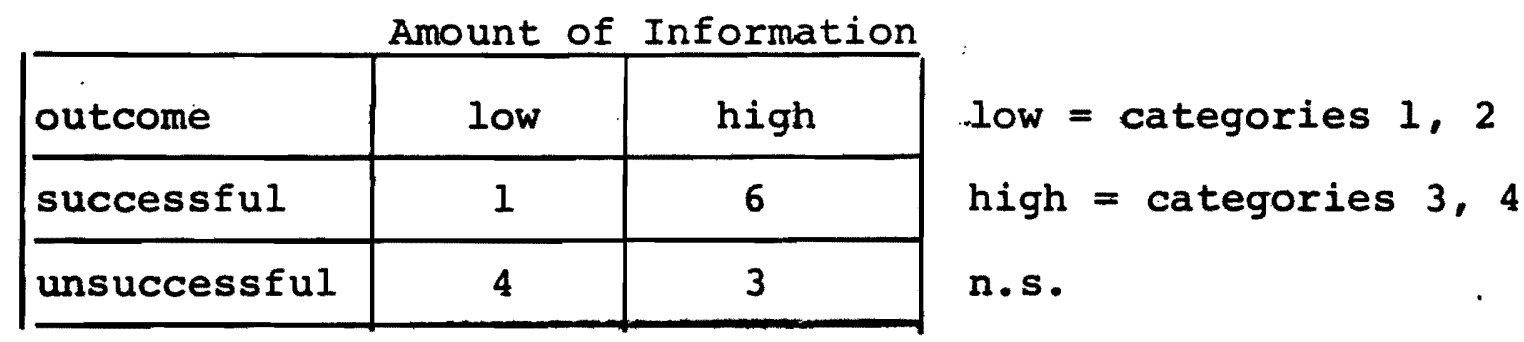

Disparity Between Recorded and Conveyed Information

Another way of illustrating the disparity between

recorded and conveyed information was by averaging the ratings

of positive information recorded in successful cases,

positive information conveyed in successful cases, positive

information recorded in unsuccessful cases, and positive

information conveyed in unsuccessful cases.

An average rating of 3.9 was found for amount of

positive information recorded in successful cases and $\underline{3.3}$

for amount of positive information conveyed in successful

cases, with a discrepancy of 0.6 . In unsuccessful cases

the average of positive information recorded was 3.7 , 
and the average of positive information conveyed was 1.7 , with a discrepancy of 2.0. This again shows a much greater discrepancy between recorded and conveyed information in unsuccessful cases than in successful cases.

With regard to negative information recorded and conveyed an average rating of 3.6 was found for recorded information, and 3.1 for conveyed information in successful cases, with a discrepancy of 0.5 . In contrast, an average rating of 3.6 was found for recorded information, and 2.3 for conveyed information in unsuccessful cases, with a discrepancy of 1.3. Once more a much greater difference between recorded and conveyed negative information was found in unsuccessful cases than in successful ones. Figure 1 illustrates graphically the gaps between recorded and conveyed information for both positive and negative information. Complete data are found in Appendix E. Thus, despite a small sample size, suggestive results were found. The results suggest that successful adoptive placements may be assocaited with the amount of information about the child and his background that is conveyed to adoptive parents.

On the assumption that negative material could be more difficult to convey, the analysis controlled for whether the information was positive or negative in character. The results held up in either case, giving indication that whether or not information is conveyed may 
Recorded Information

Conveyed Information

A. Comparison of Positive Information Recorded and Conveyed in Successful Cases

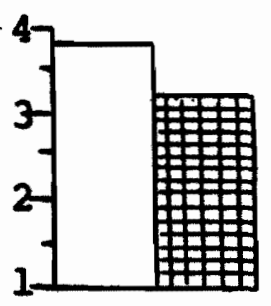

B. Comparison of Positive Information Recorded and Conveyed in Unsuccessful Cases

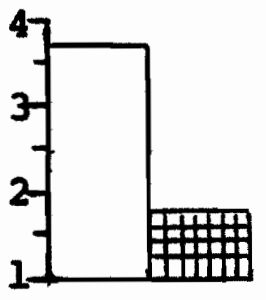

C. Comparison of Negative Information Recorded and Conveyed in Successful Cases

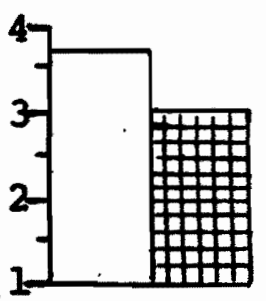

D. Comparison of Negative Information Recorded and Conveyed in Unsuccessful Cases

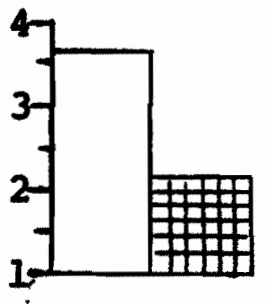

Figure 1. Gaps between recorded and conveyed information. 
be a crucial factor in successful adoptive placements. The amount of information available in the record was not a factor, further validating that information transfer is the issue.

\section{A Closer Look at Amount of Recorded Information}

Consideration was given to how the quantity of data differed by category. In order to do this the raw data were reexamined (see Appendix B) and each discrete fact was coded. Categories remained, as before, $a=$ nothing, $b=$ description, $c=$ background, $d=$ behavior (see page 41 ). A tally of the coded discrete facts is found in Appendix F. Comparing successful and unsuccessful cases, there are more positive items of information for successful cases (139) than for unsuccessful cases (98) (see Table 5). on the other hand, the amount of negative information is almost identical for successful and unsuccessful cases. In both successful and unsuccessful cases there was more negative information than positive information. The most amount of positive information is in category $d$, "behavior," the least amount in category $b$, "descriptive." The most amount of negative information, for both successful and unsuccessful cases, falls in category c, "background," and the least amount falls in the descriptive category. This shows that the records have relatively the least information about the description and health of the child, 
positive and negative, and that there is a preponderance of negative background information.

\section{TABLE 5}

ITEMS OF RECORDED INFORMATION IN SUCCESSFUL AND UNSUCCESSFUL ADOPTIONS

Type of Information

a. Nothing

b. Descriptive

c. Background

d. Behavior
Successful Adoptions Info.

0 30

49

60

139
Info.

0

19

118

36

173
Unsuccessful Adoptions Positive Negative Info. Info.

0 14 108

57

58

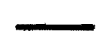

98

179

\section{A Closer Look at Conveyed Information}

In information conveyed to adoptive parents many fewer items of specific information were found in the record than the actual study of the child contained. This is to be expected as the worker who conveyed the information would not write down a complete history again, but this also makes it hard to find out how complete the record is with regard to the actual amount of information conveyed.

To show the amount of information conveyed the discrete pieces of information in each of the four categories were counted for successful and unsuccessful adoptions respectively. 
The total picture emerged as follows:

\section{Successful Adoptions}

19 discrete items of information positive 23 discrete items of information negative 42 discrete items of information total

\section{Unsuccessful Adoptions}

7 discrete items of information positive

12 discrete items of information negative

19 discrete items of information total

More than twice as many pieces of discrete information were conveyed for successful adoptions than for unsuccessful adoptions (see further breakdown, see Appendix G)

To get some idea of what the records show as to what was shared a list was compiled respectively for successful and unsuccessful adoptions. Where a specific item of information was mentioned in more than one record the item was only acknowledged once on the list. These lists give us some idea of how much the parents know about the child prior to placement.

For example, the compiled list for the unsuccessful adoptive group includes: nothing, mention of previsit(s), sharing of child's chronology such as failure of independent adoption and rejection by natural mother, knowledge of child's tendencies to withdraw from people, child abuse by natural mother, lived with natural mother for two years and problem behavior. The compiled list for successful adoptive group includes: nothing, mention of previsit(s), awareness of tonsilectomy and adenoids out and recuperation, 
aware of past poor eating habits, aware of background and names of other children in foster care, photos of the past, hard to reach child, knows all about background and behavior as they were foster parents for a long time, progress and problems of child, know about foster family as they became uncle and aunt, child has no remembrances of natural father, physically uncoordinated and will get others to perform chores for him, groans and grunts to make tasks appear harder, lacks self assurance, tries but does often not succeed, knows about ear problems and allergies, sees natural mother's problems as environmental, meets with foster parents to get information about child's behavior, know natural mother in mental hospital, know about possibilities of brain damage, about natural mother's adoptive mother causing problems, know about car accident, knows how boy is to be handled when he gets mad, know boy is fighter, know about boy's sex games, slow in school.

These compiled lists were then broken down to compare the number of successful and unsuccessful cases that show evidence of conveying the information both positive and negative to ascertain whether the manual was followed concerning the placement procedure.

The records of conveyed information show that in one successful adoption and in two unsuccessful adoptions there was nothing mentioned at all about the placement process (category A, see p. 42). In six successful and 
and five unsuccessful adoptions there is information available in the record that previsit(s) did take place before the final placement was made (category B). This seems to indicate that the procedures for one or sometimes more visits is followed. Whether the worker actually did spend time with the adoptive couple afterwards to debrief the previsit cannot be discovered from the records.

In six of the successful cases positive information about the child's background and in three of the successful cases negative information about background was shared. This compares with no positive information and two cases of negative information that was shared in the unsuccessful adoptions concerning the child's background (category $C$ ). This difference for the two groups supports our hunch that the parents cannot help the child with his identity when no information about his background is obtained. This deficit might also interfere with the parents' acceptance of the child as different from them or any natural born children.

With regard to category $D$ which includes behavior, description and medical information of the child, there is also a difference in conveyed information among the two groups. Successful cases show positive information conveyed in four cases whereas unsuccessful cases have nothing positive conveyed in this area. Negative information was conveyed in six cases for successful adoptions and in 
two cases for unsuccessful adoptions. If the record gives us a picture of what is conveyed to the adoptive couple, it certainly seems the placement process itself is not as fully emphasized as the study of the child or the study of the potential adoptive couple. It appears that more time and effort goes into the two above mentioned studies than into the important placement process itself if the record is an indication. The procedure to follow is clear for all three procedures as spelled out in the SPWC Manual. 
CHAPTER V

CONCLUSIONS, IMPLICATIONS AND RECOMMENDATIONS

Conclusions

1) Considering information recorded, there is no difference between successful and unsuccessful cases with regard to either positive or negative information.

2) The most important finding of the study is that more positive information was conveyed in successful cases. than in unsuccessful ones. There is also more negative information conveyed in successful cases, although this difference is less marked and not statistically significant.

3) Confirming these results a discrepancy of 0.6 was found between the average ratings of recorded and conveyed positive information in successful cases, and a discrepancy of 2.0 was found for the same in unsuccessful cases. A discrepancy of 0.5 was found between recorded and conveyed negative information in successful cases, while a discrepancy of 1.3 was found for the same in unsuccessful cases.

4) There are more positive discrete items of information recorded for successful cases (139) than for unsuccessful ones (98), while the number of negative items of information recorded are the same for successful and unsuccessful cases.

5) More than twice as many discrete items of information were conveyed for successful adoptions (42) than for unsuccessful ones (19). 
6) More specific findings about conveyed information included, for the 7 successful and 7 unsuccessful cases:

a. Regarding positive information about the child's background, in six of the successful cases this was shared, as compared to zero cases of sharing in unsuccessful cases.

b. Regarding negative information about the child's background, in six of the successful cases this was shared, while in three of the unsuccessful cases this was shared.

c. Regarding positive behavioral, descriptive and medical information about the child, this was conveyed in four successful cases and in zero unsuccessful cases.

d. Regarding negative behavioral, descriptive and medical information about the child, this was conveyed in six successful cases, and in two unsuccessful ones.

\section{Implications}

The reader is reminded that the purpose of this study was to discover and generate hypotheses about the adoption process, not to test hypotheses. Despite the small sample the results do point to hypotheses well worth considering:

1) The more information about the child and his background is conveyed, the more likely the adoption is to succeed. That is not to presume that simply conveyance 
of information is enough--it is only a minimum requirement. Beyond conveying of information, exploring and working through the meaning of that information on a feeling level is necessary for successful adoption to take place.

2) The more positive information conveyed, the more likely the adoption is to succeed. The concept of positive intent is importnat as related to this. This is the positive intention behind a neutral or even negative act. For example, the natural parent's giving up the child for adoption may be seen in terms of rejection, or at best, of apathy. viewed in light of positive intent, their giving up of the child may be interpreted as their wishing a better future for him with adoptive parents who are better equipped to supply his needs, physically and emotionally. Since most actions are characterized by ambivalence, seeking the positive intent is simply emphasizing the positive component of the ambivalent act. The goal is for both the child and the adoptive parents to feel stroked and supported during the particularly stressful period of the adoption process and the equally stressful period of adjustment which follows.

3) How information is conveyed is probably as important as what is conveyed. The worker is a role model for the parents--the way he deals with the couple influences the way they will deal with the child. He can model openness, ability to share feelings, positive intent to help the couple get started in the process of integrating the adopted child into their family. 
4) It might be thought that more positive information was conveyed in successful cases because more positive information was available in those cases, in other words a more positive child with greater assets is more likely to experience successful adoption. However, emphasis again must be placed on the fact that no difference was found in the amount of positive information recorded in successful and unsuccessful cases. The disparity occurs in the amount of positive information conveyed, which is much greater in the case of successful adoptions. This gives the researchers hope, as it is a factor subject to change via social work practice, not an unalterable situation.

5) The importance of the amount of information conveyed to the adoptive parents about the child and his background lies in its being a necessary tool for the parents to help the child complete his developmental tasks, especially identity formation. In order for the child to know who he is, he must have data to help him establish a sense of personal identity. Much of these data have to do with his natural parents--who they were, how they lived, what they looked like. Although the older child will know some of these facts, simply from having lived with his natural parents for five to eight years, there will be details that he has forgotten, or has never noticed but begins to be curious about as he grows up in the adoptive home. What kind of work his father or mother did, who his 
grandparents were, how his parents met, are examples of information he may want to know as he gets older, which he needs to get a full sense of personal identity. The more access he has to such data, the easier it will be for him to develop. The child also needs to complete his social identity, and come to grips with becoming an adopted child, being different from his adoptive parents, and yet belonging with them. In order for him to complete this process of social identity formation, the adoptive parents must help him, particularly by accepting the differences between him and themselves. To accomplish this they must have access to background information about the child and his natural parents.

6) The effects of separation on the adopted child cannot be stressed too much. Mastery of the feelings of anxiety stirred up by being placed with new parents, mastery of the fear of possible separation from these new parents, and mastery of the fear of psychological closeness to the new parents, are all additional developmental tasks that the adopted child must accomplish knowledge of. All of these fears can be extremely useful to adoptive parents if shared with them in a positive constructive fashion by the worker, both to anticipate and work through the difficult process of adoption. 
Recommendations for Practice

Due to the importance of information conveyed to the adoptive parents that this study indicates, many of the recommendations involve facilitating such conveyance.

The first barrier to clear conveyance of information in the adoption process is the change of caseworkers from child worker to adoption worker which takes place when the child changes county of residence. The result has three negative effects:

1) The child worker who has worked most closely with the child and has the most complete information about him and his background does not convey this information to adoptive parents. Instead, the adoptive worker secures this information from the records of the child worker, and relates it second-hand to the adoptive parents.

2) The child, who is experiencing separation from his natural parents, suffers a second separation of significance, from his caseworker.

3) The child worker is likely to have known the natural parents personally and to have conveyed some sense of acceptance of them to the child. This is unlikely for the adoption worker so the transfer is a break in continuity for the child.

On the basis of these three facts, it is highly recommended, if at all possible, for one caseworker to consistently follow the child.

What became most clear in the course of this research study was the difficulty and complexity of the tasks facing the adoption worker. It takes a worker with developed social work skills to make decisions about what information to convey, when and how to convey it in a constructive way 
in order to help the adoptive parents participate in working through this shared information and thus help the child with developmental tasks relating to separation, identity formation and integration into an adoptive home. It is recommended therefore that adoption workers receive specialized training in child development with emphasis on the developmental tasks unique to the adopted child, and the behaviors that may be anticipated in the child as a likely result of the stress of adoption. Training should be equally focused on exploring areas likely to trouble adoptive parents to prepare the worker for helping adoptive parents to work through these difficulties. Emphasis during training should be on developing skills in the worker related to helping the parents and child work through feelings and fears. The caseworker should know the phases of grief and separation, and where the child is in this process, and be able to convey this knowledge to the adoptive parents. The importance of previsits and visits during, the supervisory period as well as debriefing with the parents after these visits during which the worker can help the parents work through conflicting feelings about the child and his background must be emphasized here again. It is essential that the worker be allowed adequate time to do this thoroughly and well. Adoption is not an easy process that simply happens with the right match of parents and child. It is complicated and difficult and requires 
working through of feelings that involve the past and present lives of the child and the adoptive parents in order to ensure the merging of their lives in the future.

Recommendations for Future Research

Since this study was limited to a study of records, only the tip of the iceberg has been made visible. clearly, interviews with adoption workers, children's workers, adopted individuals and adoptive parents would yield a wealth of information related to factors involved in successful adoptions.

Interviews with workers might be designed to tap their feelings about the placement process and explore their ideas about how it could be improved upon to encourage greater success.

Adopted individuals, adolescent and adult, might be interviewed and asked what they have wanted to know about their background, and whether this data was made available to them. Their feelings and thoughts about the adoption process might be extremely helpful in sensitizing adoption workers.

Similarly, adoptive parents might be interviewed and questioned about their areas of difficulty in the adoption process. Were there areas they could have used help with, or were there areas they did receive help with, that they feel were of importance to the success of the adoption? Did they make use of conveyed information, 
and if so, how? Were they able to share negative information with the child? What were their feelings about negative information?

In addition, other variables relating to adoption might be researched in future studies. Among these are adoptive parents' expectations of the adopted child, number of casework interviews with the adoptive parents, adoption worker's sensitivity to problem areas, and amount of adoption worker's professional training.

Finally, agencies might experiment with alternative ways of organizing the adoption process in order to assess whether direct access by adoptive parents to the fullest amount of information about the child would indeed result in more successful adoptions. Each alternative strategy can be expected to pose its own problems which would need to be explored. The role of information, both positive and negative, in identity formation for the adoptive child is an area that needs detailed study. 
FOOTNOTES

1. Oregon SPWC Staff Manual, 7-15-63, Manual Letter \#III-20, Vol. III, 3408 .

2. Oregon SPWC Staff Manual, Revised 4-22-68, Manual

Letter \#III-42, Vol. III, 3413.3.

3. Ibid., 3413.5 .

4. Ibid., 3413.6 .

5. Ibid.

6. Ibid.. 3413.7 .

7. Committee on Standards for Adoptive Services, Standards for Adoption (New York: Child Welfare League of America), 1959, p. 27.

8. Ibid.

9. Ibid., p. 28.

10. Ibid., p. 27.

11. Michael Shapiro, A Study of Adoptive Practice (New York: Child Welfare League of America), 1956, p. 86.

12. Ibid.

13. Ibid., p. 87.

14. Ibid.

15. Ibid., p. 86 .

16. Iris Goodace, Adoption Policy and Practice (London: George Allen and Unwin, Ltd.), 1966, p. 67.

17. Ibid.

18. Ibid., p. 68 .

19. Ibid.

20. Lela Costin, "The History Giving Interview in Adoption Procedures," Readings in Adoption, Evelyn Smith, ed. (New York: philosophical Library), 1963, p. 343. 
21. Ibid., p. 344 .

22. Goodace, p. 69.

23. Ibid.

24. Ibid.

25. Ibid., p. 72 .

26. Ibid.

27. Ibid., p. 73.

28. Costin, p. 344 .

29. Velma Bell, "Special Considerations in the Adoption of older Children," Social Casework, Vol. 40(6) (June 1959), p. 328 .

30. Alfred Kadushin, Adopting Older Children (New York: Columbia University Press), 1970, p. 47.

31. Ibid., p. 50 .

32. Lois Beemer, "Supervision After Adoptive Placement," Readings in Adoption, Evelyn Smith, ed. (New York: Philosophical Library), 1963, p. 327 .

33. Bell, p. 328 .

34. Anne Leatherman, "Placing the older Child in Adoption," Children, Vol. 4(3) (May-June 1957), p. 110.

35. Ibid., p. 111 .

36. Anne Leatherman, "Placing the Older Child in Adoption," Readings in Adoption, Evelyn Smith, ed. (New York: Philosophical Library), 1963, p. 229.

37. Beemer, p. 328.

38. Bell, p. 330 .

39. Leatherman, Children, p. 113.

40. Kadushin, p. 6 .

41. Costin, p. 345.

42. Ibid., p. 346 . 
43. Ibid., p. 348 .

44. Ibid.

45. Ibid., p. 351 .

46. Ibid., p. 352 .

47. Ibid., p. 353 .

48. Ibid., p. 354 .

49. Barbara B. Solomon, "Conceptualization of Identity in Social Work Practice," Social Service Review,

Vol. $41(1)$, p. 2 .

50. Ibid., p. 3 .

51. Ibid., p. 4 .

52. Joseph G. Ansfield, The Adopted Child (Springfield, Illinois: Charles C. Thomas), 1971, p. 44.

53. Jean Seglow, Growing Up Adopted (London: Natural Foundation for Education, English and Wales), 1972, p. 164.

54. Erik Erikson, Identity Youth and Crisis (New York:

W.W. Norton and (o., Inc.), 1968, pp. 91-141.

55. Ibid.. p. 103 .

56. Ibid., p. 101 .

57. Ner Littner, Some Traumatic Effects of Separation and Placement (New York: Child Welfare League of America) p. 7 .

58. Ibid., p. 8 .

59. Ibid., p. 9.

60. Erikson, p. 114 .

61. H. David Kirk, Shared Fate (London: The Free Press of Glencoe, Collier MacMillan Limited), 1964, p. 115.

62. Erikson, p. 123.

63. Ibid., p. 124 .

64. Ibid., p. 126. 
65. Kirk, p. 168 .

66. M.L. Kellmer Pringle, Adoption Facts and Fallacies (London: Longmans), 1967, p. 261.

67. Kirk, p. 167.

68. Ibid.. p. 158.

69. Kadushin, p. 370. 
Ansfield, Joseph G. The Adopted Child. Springfield, Illinois: Charles c. Thomas, Publisher, 1971.

Bell, Velma. Special Considerations in the Adoption of older Children. Social Casework, vol. XI, no. 6, June 1959.

Brooks, Lee $M$. and Brooks, Evelyn C. Adventuring in Adoption. Chapel Hill: The University of North Carolina Press, I969.

Committee on Standards for Adoptive Service. Standards for Adoption. New York: Child Welfare League of America, 1959.

Erikson, Erik. Identity, Youth and Crisis. New York: W.W. Norton and Co., Inc., 1968.

Gallagher, Eleanor G. The Adopted Child. New York: Reynal and Hitchcock, $1 \overline{936 .}$

Goffman, Erving. Stigma. Englewood Cliffs, New Jersey: Prentice-Hall, Inc., 1963.

Goodace, Iris. Adoption Policy and Practice. Iondon: George Allen and Unwin, Ltd., 1966.

Harris, Thomas A. I'm O.K., You're O.K. New York: Harper and Row, Publishers, 1963.

Jaffee, Benson and Fanshel, David. How They Fared In Adoption: A Follow-Up Study. New York: Columbia University Press, 1970.

Kadushin, Alfred. Adopting Older Children. New York: Columbia University Press, 1970. - Reversibility of Trauma: A Follow-Up study of Children Adopted When Older. Social Work, $12(4)$, pp. 22-23.

Kirk, H. David. Shared Fate. London: The Free Press of Glencoe, Collier-Macmillan Iimited, 1964.

Leatherman, Anne. Placing the Older Child in Adoption. Children, vol. 4, no. 3, May-June 1957, Rp. 107-113.

Iittner, Ner, M.D. Some Traumatic Effects of Separation and Placement. New York: Child Welfare League of America, 1971. 
Lynd, Helen. On Shame and the Search for Identity. New York: Harcourt, Brace and Co., 1958.

McWhinnie, Alexina M. Adopted Children, How They Grow

Up. London: Routledge and Kegon Paul, 1967.

Murphy, Lois Barclay. The Widening World of Childhood.

New York: Basic Books, Inc., 1962.

Pringle, M.L. Kellmer. Adoption Facts and Fallacies.

London: Longmans, 1967.

Raymond, Louise. Adoption and After. New York: Harper and Brothers Publishers, 1955.

Sants, H.J. Case Studies On Effects of Deprivation of Knowledge of Natural Parents and the Apparent Need for Such Knowledge in Satisfactory Mental Health. British Journal of Medical Psychology, vol. 37, $1964, \mathrm{p} .133$.

Seglow, Jean. Growing Up Adopted. London; Natural Foundation for Education, English and Wales, 1972.

Senn, Milton J., M.D. and Solnit, Albert J. Problems in Child Behavior and Development. Philadelphia: Lea and Febegir, 1968.

Shapiro, Michael. A Study of Adoptive Practice. New York: Child Welfare League of America, Inc. 1956.

Smith, Evelyn. Readings in Adoption. New York: Philosophical Library, 1963.

Chapter 28. Beemer, Lois. Supervision After Adoptive Placement, pp. 323-332.

Chapter 30. Costin, Lela. The History Giving Interview in Adoption Procedures, pp. 343-356.

Chapter 18. Leatherman, Anne. Placing the Older Child in Adoption, pp. 220-231.

Solomon, Barbara B. Conceptualization of Identity in Social Work Practice. Social Service Review, vol. 41, no. 1 , pp. 1-9.

Weeks, Neville B. Adoption For School-Age Children in Institutions. New York: Child Welfare League of America, Inc.

Yarrow, L.J. Theoretical Implications of Adoption Research. Child Welfare, vol. 44, no. 21, 1965 , pp. 65-72. 
APPENDIX A 
AMOUNT OF INFORMATION IN THE RECORD

\section{CHILD \#1}

\begin{tabular}{ccccc} 
Worker & $\begin{array}{l}\text { Number of } \\
\text { Placements }\end{array}$ & $\begin{array}{l}\text { Variables Related to the Child } \\
\text { Health, Mental } \\
\text { and Physical }\end{array}$ & $\begin{array}{l}\text { Preparation of Child } \\
\text { for Adoption }\end{array}$ & $\begin{array}{l}\text { Adjustment in } \\
\text { Foster Home }\end{array}$ \\
\cline { 2 - 2 } & 4 & 3 & 1 & 4 \\
B & 4 & 3 & 1
\end{tabular}

\begin{tabular}{ccc}
\multicolumn{2}{c}{ Variables Related to Adoptive Parents } \\
\cline { 2 - 4 } & Experience in Parenting & Expectations \\
\hline 2 & 4 & 2 \\
2 & 4 & 2
\end{tabular}

Variables Related to Worker

\begin{tabular}{ccc} 
Ability to Assess Parents & $\begin{array}{l}\text { Preparation of Parents } \\
\text { for Specific Child }\end{array}$ & $\begin{array}{c}\text { Amount of Supportive } \\
\text { Services }\end{array}$ \\
\hline 3 & 1 & 1 \\
3 & 1 & 1
\end{tabular}




\section{(Continued) \\ CHILD \$2}

Variables Related to the Child

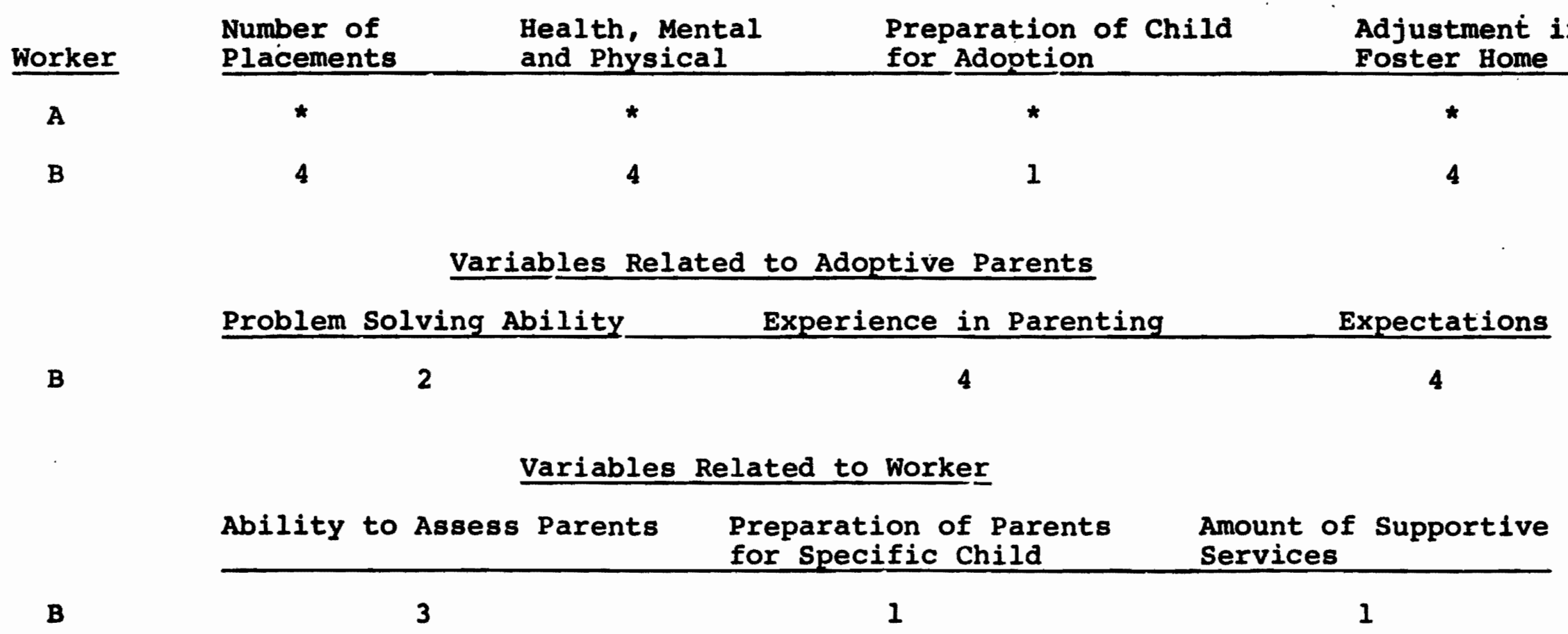




\section{(Continued)}

CHILD $\$ 3$

Variables Related to the Child

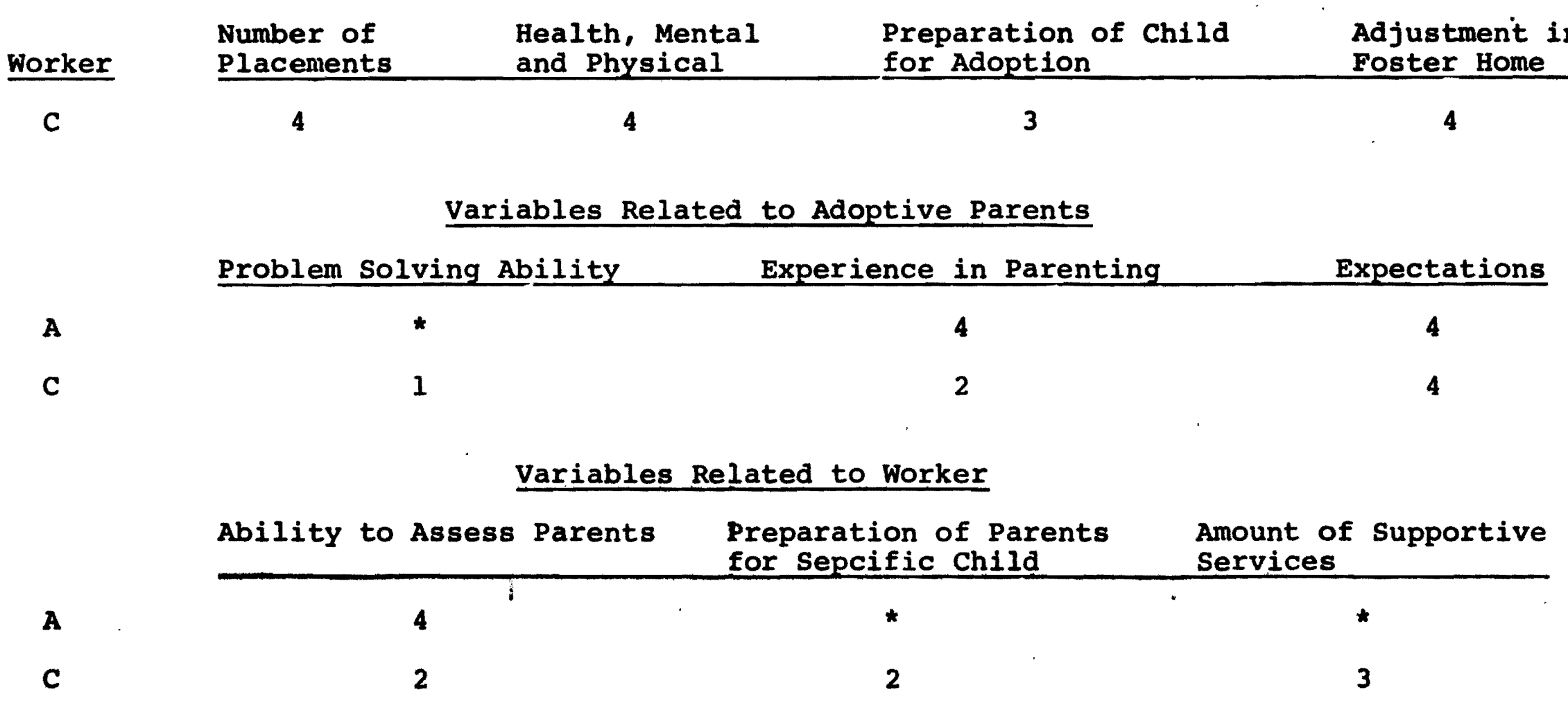

* Partial examination of record due to time limitations did not allow for scoring this category. 
APPENDIX B 
CASE \#1

Recorded Information

Positive

father completed 12th grade

father medium height, dapper moustache

no previous marriage for

father

mother completed loth grade

mother has long, dark brown hair

grandparents always concerned for children and visited

children in foster care

grandparents provided children with some sense of family

identity

children attrative girls

both have brown hair

children twin girls

$x$ is outgoing

$\mathrm{X}$ relates well to foster parents

X somewhat shy

Y. relates well to foster parents

Both in good health at present $X$ shy at first but has developed more social skills with time
Negative

father has "weasel-like" face

father incarcerated in OCI

children in care because of

mother neglect--"undernourished"

mother repeatedly left children

in care of grandparent, unable

to provide care for children

children made wards of court in 1966, put in foster care and remained there until 1971-this year parental rights terminated

natural father itinerant parents--frequent assistance recipients

father had no special employment skills

$X$ small height for age, below average in weight

lived in 2 foster homes, 3 years in first and 2 years in second, small child

$X$ undernourished, weakness

in arm, difficulty teething

problem regarding anal retention, difficulty passing feces

at 1 month had seizure--no more later

history of falling off natural mother's lap and bumping head at 3 months 
CASE \#1 (Continued)

Positive

X 105 IQ, friendly

$\mathrm{X}$ enthusiastic, warm

$X$ no brain damage

seven siblings including twins
Negative

blockage of tear duct, coughed nightly due to asthma and allergies

child's milk caused heavy mucus

afraid of loud noises and sudden moves

afraid of being alone

had younger sister released by mother for adoption

2 older brothers--1 retarded, other hyperactive

$X$ does well in school

$Y$ slow to develop, clings to twin sister and dependent on her to initiate activities

$x$ won't try anything other

$Y$ not promoted in first grade

\section{Conveyed Information}

Positive

evidence that worker shared some background material regarding other homes, namely foster homes

mention of visits
Negative

evidence of such problems as possible brain damage in $\mathrm{x}$ from being dropped on head-"had expected this"

some resentment on $X$ 's part at first

$Y$ slower in school as expected mention of visits 
CASE \#2

\section{Recorded Information}

\section{Positive}

child medium dark skin

appealing child

rolled over at two months

smiled at six weeks

physically strong baby

did not cry in hospital

at two and one-half healthy

child wanted back to first home

sensitive child

fourth foster home knows child's history and helps him accept accident where son of potential adoptive couple died

worker shows child hospital where he was born and first foster home to help him overcome confusion about himself and his family

handsome

well coordinated

mother of average intelligence

father tall and healthy

child adoptable at birth

\section{Negative}

black father and white mother mother unmarried

mother declared unable to care for child by court before birth of child

nice physical description of mother

mother little emotional affectflat

foster mother adopted

mother's adoptive mother neurotic need to make all decisions for adopted daughter

mother sociopathic personality

mother--drinking, stealing, aimless low level of anxiety

mother delinquent in St. Mary's, Hillcrest 1957-1960

Oregon State Pen for kidnapping

mother declared incompetent 1966

child lost weight for seven days in hospital

second foster parents ambivalent about adoption for long time

moved to third foster home

returned to second foster home, they want to adopt

active, needs limits 
Negative

second foster mother trouble controlling child

boy became belligerent and difficult

financial trouble in second foster home

foster mother wants to replace her dead son

boy goes on crying sprees

boy rejects second foster parents

stress in foster home

couple ineffective

boy out of control

fourth foster home also another black child there

child hostile, agressive and baby talk at first

visits to former foster family detrimental, confuses child

second foster family do not want to adopt child now

child injured in accident with second foster family's boy (boy killed)

second foster home used before and after third foster home 
CASE \#2 (Continued)

Conveyed Information

Positive

four placement visits accepting of boy

sees natural mother's problems as environmental

meet with foster parents to get information about child's behavior
Negative

four placement visits

knows about child's background

knows about natural mother in mental hospital

knows about possibility of

brain damage

knows about natural mother's adoptive mother

knows who caused problems because of her decision making

knows about car accident

knows how boy was handled when he got mad in foster homes

knows boy is fighter

knows about boy's sex games 


\section{CASE \# 3}

\section{Recorded Information}

Positive

blonde, pretty, brown eyes

loves her dog

plays well by herself

ways of handling tantrums

sat up at four months

walks at thirteen months

potty trained at two

does well in foster home

no more scenes

sense of humor now

sharing possessions with other children

good health

eats well

no longer has imaginary

friend

\section{Negative}

placed in foster care at two months because of mother's surgery

returned to mother

returned to foster care soon after

child of common law relationship

mother then married other man

mother in prison

ward of court at $1-1 / 2$ years old

released for adoption at $3-1 / 2$

characteristics of mother

5 feet 3 inches

mother's mother married twice

girl shy

fluid in ears

tantrums, bad temper

bowel trouble

allergies

nothing about natural father

several foster homes

some hearing loss 
CASE \#3 (Continued)

Conveyed Information

Positive

previsit

knows about foster home
Negative

previsit

knew about ear problems and allergies, same doctor as before placement 


\section{Recorded Information}

Positive

Father white, 8 th grade education, born 4-23-33 Texas, Protestant, cook, Sapnish American. Mother, now deceased, born 4-19-44, white Protestant, H.S.G 2 siblings, boy and girl. Father dark complexioned and Mexican in appearance. Mother of average intelligence. Mother has dark eyes, thick lips, complexion Indian or Negroid, light brown hair. Tall. Originally 2 siblings (twins) and child separated for foster placement, then together. Good adjustment with each other and foster parents.

Mother visited child occasionally while in foster care, seemed to want to "make it up" to him. Three children accpeted her as friend who came to visit. $x$ only one who cried when told of her death.

No serious illness. Few medical or dental needs. $x$ considered intelligent and quick to learn. $X$ is a tease. Attended Head start classes--associated with peers in competitive activity-helpful stimulus. Born in Yuma, Arizona. Sensitive to feelings of other family members, easily moved and very sympathetic. Mentally sharp, curious, seeks answers, ahead of many other 6-year-olds. Has gotten over feelings of insecurity. Good appetite. Emotionally even-tempered without tantrums or sulking. Close family attachment and will be
Negative

Parents first apply for assistance $5 / 65$ because of father's temporary unemployment. Mother applies in 166 when husband deserts, may have fled to Mexico. Father was an "undependable employee." Mother had many problems, emotionally incapable of providing proper care. 167 she requests foster care, children placed 3/67. Mother intimates that father had police record several states. Very few contacts with father-not much known about him. Mother describes marriage as lukewarm, not happy because of age difference and his nationality. Said there was lack of communication. She is thin and nervous and shook uncontrollably during interviews. May have had epilepsy. Often became depressed over rejections and insecurity since early age. Never able to communicate love to her children. Low tolerance level for behavior of even normal children. Continually disorganized, thoughtless, very poor organizer. Very ill with kidney problems, high blood pressure (while in California where moved and lived with another man). After children placed in foster care hospitalized, died in Oregon after kidney transplant University of Oregon Medical School 5-20-71 (27 years old). Mother refused to release children for adoption as she had been adopted from a foster 
CASE \#4 (Continued)

Positive

the most disturbed over separation from foster parents. Dark complexioned with medium dark skin, hair and eyes. Normal height and weight. Friendly, talkative. Wants to be noticed and given attention.

Mother wanted to become architect or interior decorator--consiäered unrealistic ambitions by worker.

\section{Negative}

home and felt was never accepted by adopted parents and ridiculed at school. Pessimistic and morbid humor. Never would admit illness was terminal. Led "sordid existence," associated with "the lowest." Children were neglected, in danger of physical harm--mother speaks of fear of choking $x$ to death in fits of frustration and anger. At age of $3 \mathrm{x}$ described by mother as hyperactive and uncontrollable. She gave him away to neighbors across the street. Locked $x$ and siblings in house or took children to neighbors filthy and starved. Then disappeared. $x$ would not talk when at home with mother prior to and at time of placement, though he could talk well for his age. $x$ sensitive and more needful of security than twin siblings. Inclined to whine and be demanding of attention. Sometimes wakes up screaming and thinks left alone.

\section{Conveyed Information}

Positive

Memo 12-7-71 from worker: I have discussed their progress and problems with adoptive parents. Continued relationship with foster parents who become children's aunt and uncle, good way to handle the transition--so adoptive parents know about foster parents.

\section{Negative}

Chilören have no remembrances of father and don't question why they have never known him.

$X$ somewhat physically uncoordinated. In some instance woula not perform to get someone else to do work for him. likes to grunt and groan with effort to make task appear harder to do. 
CASE \#4 (Continued)

Positive

Negative

Lacks self-assurance. Tries but doesn't often succeed. Makes hard work out of simple tasks.

Clumsy and awkward and poorly coordinated. 
CASE $\$ 5$

Recorded Information

Positive

cute blonds six-year-old

no health problems

regards self as part of foster family

but knows she is foster child

gets along with peer group

continuous love in first

foster home

relatively free of emotional problems

good health
Negative

placed out after birth, changed to second foster home

ward of court 6-17-66

parents no contact with child

natural father not husband, child from short affair

third foster home in

December 166

no contact with family even though in area

mother gave up other children

natural mother sends presents

natural mother changes her story and lies about information

Conveyed Information

Positive Negative

All known about background and behavior as they were foster parents for a long time. 
CASE \#6

Recorded Information

Positive

father--a manual worker, short, wiry

mother described as intelligent and gregarious

no relatives who would have effect on child's adjustment to adoptive home

no contact with any relatives since 1969

child is attractive, blond, small for age, average weight, delicate feminine appearance

healthy child

worker observes child eats in average time

worker observes child to smile warmly

worker observes child to be talkative, seemed trusting of worker and in need of attention from her

child observed arguing with foster parent's child over toys

child is one of 3 other foster children in foster home ( 2 boys age 6 and 7) Foster parents have 2 own daughters aged 10-1/2 and 4

little contact for girl with relatives since placed with agency

child placed on vitamins and iron--when this done blood count rose quickly
Negative

child and siblings referred by out of state welfare department regarding neglect, lack of parental supervision. Kids in foster care one week and returned to parents with CSD support. Next year again placed in foster care due to parental neglect

Same year children made wards of court to remain in CSD custody

parents last saw children December ' 68

child's parents separated ' 69 child's father released her for adoption on December 170

natural mother married twice

natural mother had history of drinking, and neglecting children

father said his family had history of being short in stature

father led hard life

father said to be heavy drinker

mother known to have drinking problem also

mother and father have limited educations

descriptions of child by psychologist as underactive, withdrawn and shy 
CASE \#6 (Continued)

Positive

child has well proportioned frame

no evidence of physical handicap

child attended kindergarten

shy at first in kindergarten

at first could not count numbers or write

child learned. to share information and kept up with other children in art. Began to show others how to do it

child has 4 half sisters and brothers still in foster care--all siblings except 1 are normal in size with no serious problems. 1 boy small of siblings

worker desires urban home, as child has little knowledge of rural life

worker says child needs children in home near own age, but not a particularly aggressive child or children

worker says child likes affection

IQ is tested at 94

child functioning intelligently at average level with average potential, excellent verbal potential IQ 130

in 1971 became "tired out" at school, would fall asleep

described as "tomboy"

\section{Negative}

sits and watches television excessively

described by foster mother as slow, lethargic and taking a long time to eat

Psychologist and foster mother describe her as inward, paying attention to self, moods and feelings, rarely shows emotion, especially positive emotions

foster parent sees her as unassertive, unenthusiastic regarding activities

worker believes 2-year-old foster parent's child may overshadow child

wants to wrestle with boys in home ages 6 and 7

foster mother says child doesn't initiate activity but enjoys it once it is begun

no contact with siblings since placed in foster care

has lived in 4 foster homes, one foster mother believes child retarded

once placed in hospital regarding possible anemia

seemed anemic because of poor appetite, slept

excessively

when in foster care at first eneuretic

soft spot in back of head that closed later 
CASE \#6 (Continued)

Positive

gets along with other children and participates enthusiastically

\section{Negative}

has elongated head, prominent veins around eyes

seen at University of Oregon regarding possibility of adenoidectomy

evidence of some hearing loss

foster mother indicated that child's school work took a dip--saying child works on certain days and not on others

sometimes refuses to do her school papers over

foster mother very resistant to idea of worker discussing adoption with child

teacher noted change in child's behavior at school when adoption discussed at first. Yelled at other children at home and would sit a long time without saying anything, would appear preoccupied

one sibling had problem of asthma and allergies since birth

foster mother resistant to adoption

child can be stubborn regarding discipline--reacts to anger by becoming indifferent

has moods which are negative

child removed under very threatening circumstances 
CASE $: 6$ (Continued)

Conveyed Information

Positive

several visitations set up with adoptive couple prior to placement

evidence that couple aware of tonsilectomy and adenoidectomy and recuperation since operation

aware of changes in eating habits over past poor eating

aware of background as child mentions having been in foster care and remembering names of people

"They were amazed as they were more prepared for a child who was rather to herself."

the child has talked of previous foster families with adoptive couple, has pictures of past

"Couple says they were worried before they met her, were kind of afraid she would be hard to reach."
Negative

several visitations set up with adoptive couple prior to placement 
CASE $\$ 7$

Recorded Information

Positive

Mother born 6-30-29, married once before 10-2-46 in

Vancouver, Washington, 3 children from this marriage, separated $3 / 60$, divorced $3 / 61$, 4 children, one died in infancy. $X$ second youngest. Mother is small petite with red hair, attractive appearance. Described consistently by workers as "bright," friendly, considerate... cooperative and receptive to casework services," gracious and pleasant, refined softspoken, quiet. She began to attend Brooklyn Service Center's Mothers Group, was enthusiastic regarding work and training.

Five-year-old child with light brown hair and blue eyes, average size, very attractive, no physical problems, extrovert, happygo-lucky, bubbling, talkative, full of life, readily adjusts to new situations, trusting and open.

Foster mother says he has no extremely unusual habits or fears. Sleeps well, no bedwetting. Plays well with siblings, makes friends, good appetite, adaptable, understands adoption

Younger of half-siblings, 14year old, $Y$ shows interest, filled mother substitute role when mother was sick and when 4 children were in foster home together.
Negative

Mother died $3 / 70$ when he is $3-1 / 2$, of pneumonia (she is 39). Father deserts mother when she is pregnant with last child (1967).

Father drinks, is abusive, violent temper tantrums. Unskilled laborer, born

Illinois 6-5-28, married and divorced previous to this marriage; was sought by police for passing bad checks. No physical description as worker never saw him.

Mother filed for divorce from father who was threat to physical well-being of mother and child. Mother died before divorce finalized. Raised 6 children alone with little money, physical and mental abuse from father. Placed children in foster care 10/68 till 2/69 voluntarily.

Father literally tore up the home. Mother very run down-2 bouts of flu and pneumonia, then dies. Sick from 10/68 till death.

Maternal grandfather shows no interest.

Child fears dark, but this doesn't keep him from sleeping. 
CASE \#7 (Continued)

Conveyed Information

Positive

Negative

None

None 
CASE \#IA

\section{Recorded Information}

Positive

mother good physical health

mother athletic

mother when employed works hard

five years old attractive sturdy

dark hair, rosy cheeks, brown eyes

smile charming

child well coordinated, athletic

good at routine

loves to be helpful

responds to praise

bright inquiring mind

loves to learn at school

positive relationship to foster father

benefitting from school experience

normal delivery

weaned at ten months

walked at eleven months

talked at eighteen months

sharing attention with other children in fourth foster home
Negative

mother gets $A D C$ at birth of son

not married

mother cruel and abusive to child

child does not get regular meals

ward of court at nine months

mother and son to Denver

when child one

when back mother requests foster care, child $1-1 / 4$ years old

before that moves around with son

foster care continued

mother lesbian, identity of boy confused

when boy 4-1/2 rights of mother terminated

natural father not known, member of Hells Angels

mother six years of schooling had poor parenting, her family traveled around, neglected by her parents

very little regular schooling of mother

delinquent behavior, runaway, drinking, promiscuity 
CASE \#IA (Continued)

Positive

cares a lot about fourth foster mother

\section{Negative}

mother difficulties forming relationships

entrenched in deviant sexual behavior

mother known to police department around country appearance of mother five feet four inches, bad teeth, tattoos, gruff speaking

child age five nervous, overactive, biting fingernails, aggressive, competitive, dislikes sharing toys and affection

tests limits

obstinate when critized

hard time getting along with other children

babied in second foster home doing better in fourth foster home

had asthma and hayfever

becomes destructive in fourth foster home to children and animals

mother's visits upset him

separation from masculine mother, she sees him as possession at $2-1 / 2$ years old

parental rights terminated at age five

relationship to mother continued, calls her sister

withdrew when told about prospective adoption 
CASE \#IA (Continued)

Conveyed Information

Positive

Negative

three previsits

mention of problems in behavior

three previsits 
CASE $2 A$

Recorded Information

\section{Positive}

very large blue eyes

blonde hair

affectionate with foster mother

shy

friends with children own age
Negative

age one does not sit up

age one does not move around

lack of affection, nutrition and stimulation in first foster home

removed from mother after at one year two months

filth of home

mother drinking

boy slow

boy stays with sister

mother rejected boy and still does but does not want to give him up for adoption

second foster home

mother married three times, five of her children in trouble

boy's legal father not natural father

boy does not like to go out alone

Conveyed Information

Positive

one previsit
Negative

one previsit 
CASE \#3A

Recorded Information

Positive

mother 5' 6" tall, 100 lbs.

mother has dark brown hair, green eyes, freckles

myopic, wears glasses, completed lith grade and passed GED, interested in clerical work

father 5' 7", 140 lbs., dark brown hair, green eyes

father completed high school with barely passing grades

child has had contact with maternal grandparents, is attached to his granddad

child is described as shy and appealing

child is 39-1/2" tall and weighs 35 lbs.

child has dark blondehair and green eyes

child enjoys being hugged

serious child

cooperative, seldom needing discipline

enjoys camping and fishing

IQ tested of 109

child made fast attachment to other children in home

functions adequately at his age level
Negative

parents received public assistance

mother described by caseworker as immature, impulsive, shallow, disorganized living style

child hates being left alone

prefers men to women

child has heart murmur

has a younger sister in

foster care

child placed in shelter

child neglected and left alone

later returned to parents who caused him to be made a ward of court under court supervision

father voluntarily relinquishes rights

father had poor employment history

father incarcerated--OCI

$X$ 's father described as withdrawn, hostile with drinking problem

father hospitalized at Dammasch for attempted suicide

information given on poor health of mother's parents 
CASE \# $3 A$ (Continued)

Positive

no evidence of retardation as a result of birth delivery

\section{Negative}

$X$ frightened by new people, often cries

$\mathrm{x}$ dislikes being teased, can't stand being laughed at some indications of abuse experience little stability or security in early life delivered by mid forcepts x jittery, hypertonic severe diaper rash with sores when little

kept in crib constantly up until 17 months

unable to walk at 17 months unable to eat solid food at 17 months

much head-bànging congenital urinary defect bad bronchial allergy suffered from empetigo suffered mild anemia possibility of adenoid problems has a lisp in speech seemed in pain when picked up acts shy and insecure when in new situation 
CASE \#3A (Continued)

Conveyed Information

Positive

Negative

evidence of knowledge of boy's tendency to withdraw from people from a letter that describes adoptive couple's application to Edgefield Lodge for help in dealing with the boy)

also information from same letter regarding the fact that couple had information that boy had lived with natural mother for first two years of life--also that child had been abused and placed in foster care 
CASE \#4A

Recorded Information

\section{Positive}

grandparents keep contact with boy

relationship with grandparents positive

adjustment to foster homes good

light skinned--mixed

very active and energetic

average intelligence

not as destructive as before

eats and sleeps well

\section{Negative}

born by unwed mother

placed in foster home after

birth

mother did not want child

second foster home at two months

third foster home at one year

mother small, fair skinned, negroid features; heavy make-up, childish speech; raised by mother, completed ninth grade

mother superficial and sociopathic

mother has juvenile record, Hillcrest, in jail for robbery, prostitution

mother does not know who child's father is

not much stimulation in foster home, so removed

fearful of fourth new foster home, sad, difficulties sleeping--afraid, unhappy, disturbed, destructive, withdrawn if he does not get his own way

agressive physically-discipline problem

ward of court early

not good social ability in school

foster mother not loving, harsh foster home 
CASE \#4A (Continued)

Conveyed Information

Positive

Negative

two previsits

two previsits 
CASE \#5A

\section{Recorded Information}

Positive

mother attractive with dark hair, 5'4" tall, somewhat overweight

mother completed 6 th grade, father completed lith grade-a carpenter by trade

the child is an attractive blonde girl with straight hair

relates well in foster care to adults and children

open child, expresses herself and her feelings

sensitive emotionally, very sympathetic

likes to be helpful, likes babies

no serious medical problems

average intelligence

worker feels child needs

home that can enjoy an open child, used to being listened to, needs home that can demonstrate love

\section{Negative}

mother came of welfare recipient family

mother on $A D C$

mother had common law husband who deserted her

mother married four times, had three children prior to this one released for adoption

1967 mother released $X$ for adoption. She was then placed in foster care with some contacts by mother--these upset girl

$1969 \mathrm{X}$ made ward of court, didn't see mother any more, child given up because mother felt she couldn't care for her

her father married previously with one child resulting

insecure about future

becomes hyperactive and loses control in large groups, family affairs or in school

does not play well with peers

her brother developed Hodgkin's disease and had to be removed from foster home both were placed in

showed lots of signs of being upset over brother's removal 
CASE \#5A (Continued)

Positive

\author{
Negative \\ feelings easily hurt \\ no prior health history prior \\ to placement \\ placed in 3 foster homes in \\ a year, prior to this lived \\ with several stepfathers-- \\ one of which very abusive-- \\ he burned $X$ with cigars, \\ beat and kicked kids \\ 1967 children released by \\ mother for independent \\ adoption; family poor couldn't \\ keep them \\ difficult for $x$ to settle \\ down in school--easily \\ distracted by others \\ wants to be adopted by foster \\ parents \\ disruptive behavior in class- \\ room \\ a psychological evaluation \\ revealed learning patterns \\ characteristic of emotionally \\ and culturally deprived \\ child, e.g., low on informa- \\ tion, arithmetic and digital \\ span sub-tests \\ lived with last foster parents \\ at least 3 years before her \\ adoption by adoptive couple
}


CASE \#5A (Continued)

\section{Conveyed Information}

Positive

evidence of plan for visits of child and couple prior to adoption

reference by worker of sharing of child's chronology with adoptive couple prior

to placement
Negative

evidence of plan for previsits reference to failure of an independent adoption and rejection by natural mother 
CASE \#6A

Recorded Information

Positive

Mother attractive, petite with light brown hair and freckles

\begin{abstract}
Appealing $5-1 / 2$ year old with brown hair, dark brown eyes and olive complexion. Maybe father Mexican. Quiet, easygoing, tends to be follower. Gets along with other children and willing to share. He and brother have close attachment to foster family and their extended family. Enjoys games, puzzles, cars, trucks and trikes. Dislikes eggs and potatoes, likes most foods. No eating or sleeping problems, no bad habits except fighting with younger brother. Loving, affectionate, needs a lot of physical contact and attention.
\end{abstract}

When worker meets child, shy but friendly, offers her flower.

9/70 adjusts easily to kindergarten. Plays well with children, willing to share, no discipline problem. strong bond with brother.
Negative

Mother severly depressed $3 / 68$, requests foster home placement, can't provide for children. Mother fails to appear at review hearing $8 / 70$ and her rights are terminated $2 / 71$. Mother comes from disorganized home; was in foster care, committed to California Youth Authority for delinquent behavior, hospitalized 3 times for attempted suicide. 1970 diagnosed by psychiatrist-passive aggressive personality disorder with emotionally unstable and antisocial features. Immature impulsive shallow, leads disorganized life. Married 12-5-64, divorced 7-18-66. Husband not father of $x$. 8-3-70 marries second husband. Natural father unknown.

$Y$ has had no contact with any relatives other than mother in over 3 years. No meaningful relationship with any relative including mother

Y can be an agitator, picks a fight, then runs away, especially with younger brother. Very competitive with brother, fight constantly. At age $1-1 / 2$ placed in hospital when mother jailed for intoxication. Later that month placed with maternal grandmother $(2 / 67)$. 3/67 back with mother, 4/67 mother deserts them, leaves with sister, then to maternal aunt, 4/67 maternal grandmother, $5 / 67$ back with mother, 
CASE \#6A (Continued)

Positive

\section{Conveyed Information}

Positive

Adoptive parents meet child. By mid-afternoon children are ready to go home with them for 3-day visit. 10-11-71 worker visits to get acquainted with boys--everything is fine.

\section{Negative}

requests foster home placement, 5/67 placed with 3 siblings, $6 / 67$ separated (no reason given), $1 / 68$ returned to mother, $3 / 68$ foster care again, 4/68 to mother, later $4 / 68$ to Waverly Children Home after mother attempts suicide, $6 / 68$ foster care, $12 / 70$ another foster care home (last one inadequate care). Report from Waverly $5 / 68$ boys were regressing, stopped using speech, insecure, disturbed. 7/68 foster mother reports first complete sentence, not toilet trained, not outgoing, quiet and passive. $12 / 70$ new foster mother reports $Y$ won't remove underpants to bathe--afraid they would laugh at him since never circumcized. 


\section{Recorded Information}

\section{Positive}

toilet trained

does not wet bed

good health

handsome

responds to reinforcement

responds to affection

thought processes in order

dull to normal or above normal intelligence

child is social

good with guidance
Negative

adopted before

natural parents killed in accident

natural mother adopted

child's personality not suited for former adoptive home

natural grandmother wanted to get rid of children

former adoptive parents sees boy as slow

boy does not pay attention to them

part Negro-Indian-Caucasian

stubborn

tantrums--acting out feelings

boy does not like aversive discipline

loses control in school

hitting behavior

defensive and controlling

anxious about separation

impoverished background

refused to go to kindergarten

in second foster home does

not relate to other children

another foster home prior to adoption 
CASE \#7A (Continued)

Positive

Negative

second adoptive home took

long time to be approved so

long time before second

adoption, close ties to last

foster family

enlarged glands, may be malignant

Conveyed Information

Negative

none

none 
APPENDIX C

$\therefore \quad+\cdots$ 
RATINGS OF AMOUNT OF POSITIVE

AND NEGATIVE INFORMATION RECORDED AND CONVEYED

\begin{tabular}{c|c|c|c|c}
$\begin{array}{c}\text { Case } \\
\text { Number }\end{array}$ & $\begin{array}{c}\text { Amount of Positive } \\
\text { Information Recorded }\end{array}$ & $\begin{array}{c}\text { Amount of Negative } \\
\text { Information Recorded }\end{array}$ & $\begin{array}{c}\text { Amount of Positive } \\
\text { Information Conveyed }\end{array}$ & $\begin{array}{c}\text { Amount of inegative } \\
\text { Information Conveyed }\end{array}$ \\
\hline 1 & 4 & 4 & 3 & 3 \\
2 & 4 & 4 & 4 & 4 \\
3 & 3 & 4 & 3 & 4 \\
4 & 4 & 4 & 4 & 3 \\
5 & 4 & 2 & 4 & 4 \\
6 & 4 & 4 & 4 & 3 \\
7 & 4 & 3 & 1 & 3 \\
\hline $1 a$ & 4 & 4 & 2 & 2 \\
$2 a$ & 3 & 3 & 2 & 3 \\
$3 a$ & 4 & 4 & 1 & 2 \\
$4 a$ & 4 & 3 & 2 & 3
\end{tabular}


(Continued)

$1=$ None

2 = Any one category except a or A

$3=$ Any two categories except a $\mathrm{A}$

$4=$ All three categories except $\mathbf{a}$ or A

[For description of categories see pp. 41-42 of study] 


\section{APPENDIX D}


COMPARISON OF

SUCCESSFUL AND UNSUCCESSFUL CASES

WITH REGARD TO INFORMATION RECORDED AND CONVEYED

TABLE I

AMOUNT OF POSITIVE INFORMATION RECORDED

\begin{tabular}{|l|c|c|c|c|}
\cline { 2 - 5 } outcome & 1 & 2 & 3 & 4 \\
\hline successful & & & 1 & 6 \\
\hline unsuccessful & & & 2 & 5 \\
\hline
\end{tabular}

TABLE II

AMOUNT OF NEGATIVE INFORMATION RECORDED

\begin{tabular}{|l|c|c|c|c|}
\cline { 2 - 5 } outcome & 1 & 2 & 3 & 4 \\
\hline successful & & 1 & 1 & 5 \\
\hline unsuccessful & & & 3 & 4 \\
\hline
\end{tabular}

TABLE III

AMOUNT OF POSITIVE INFORMATION CONVEYED

Amount of Information

\begin{tabular}{l|c|c|c|c|}
\cline { 2 - 5 } outcome & 1 & 2 & 3 & 4 \\
\hline successful & 1 & 0 & 2 & 4 \\
\hline unsuccessful & 2 & 5 & 0 & 0 \\
\hline
\end{tabular}


(Continued)

TABLE IV

AMOUNT OF NEGATIVE INFORMATION CONVEYED

\begin{tabular}{|l|c|c|c|c|}
\cline { 2 - 5 } outcome & 1 & 2 & 3 & 4 \\
\hline successful & 1 & 0 & 3 & 3 \\
\hline unsuccessful & 1 & 3 & 3 & 0 \\
\hline
\end{tabular}


APPENDIX E 


\section{DIFFERENCES BLTWEEN POSITIVE RECORDED} AND POSITIVE CONVEYED INFORMATION

\begin{tabular}{|c|c|c|c|}
$\begin{array}{l}\text { Successful } \\
\text { Cases }\end{array}$ & $\begin{array}{l}\text { Recorded } \\
\text { Information }\end{array}$ & $\begin{array}{l}\text { Conveyed } \\
\text { Information }\end{array}$ & Differences \\
\hline 1 & 4 & 3 & 1 \\
\hline 2 & 4 & 4 & 0 \\
\hline 3 & 3 & 3 & 0 \\
\hline 4 & 4 & 4 & 0 \\
\hline 5 & 4 & 4 & 0 \\
\hline 6 & 4 & 4 & 0 \\
\hline 7 & 4 & 1 & 3 \\
\hline Totals & 27 & 23 & 4 \\
\hline Averages & 3.9 & 3.3 & 0.6 \\
\hline
\end{tabular}

\begin{tabular}{|c|c|c|c|}
$\begin{array}{l}\text { Unsuccessful } \\
\text { Cases }\end{array}$ & $\begin{array}{l}\text { Recorded } \\
\text { Information }\end{array}$ & $\begin{array}{l}\text { Conveyed } \\
\text { Information }\end{array}$ & Differences \\
\hline $1 a$ & 4 & 2 & 2 \\
\hline $2 a$ & 3 & 2 & 1 \\
\hline $3 a$ & 4 & 1 & 3 \\
\hline $4 a$ & 4 & 2 & 2 \\
\hline $5 a$ & 4 & 2 & 2 \\
\hline $6 a$ & 4 & 2 & 2 \\
\hline $7 a$ & 3 & 1 & 2 \\
\hline Totals & 26 & 12 & 14 \\
\hline Averages & 3.7 & 1.7 & 2 \\
\hline
\end{tabular}


(Continued)

DIFFERENCES BETWEEN NEGATIVE RECORDED

AND NEGATIVE CONVEYED INFORMATION

\begin{tabular}{|c|c|c|c|}
$\begin{array}{l}\text { Successful } \\
\text { Cases }\end{array}$ & $\begin{array}{l}\text { Recorded } \\
\text { Information }\end{array}$ & $\begin{array}{l}\text { Conveyed } \\
\text { Information }\end{array}$ & Differences \\
\hline 1 & 4 & 3 & 1 \\
\hline 2 & 4 & 4 & 0 \\
\hline 3 & 4 & 4 & 0 \\
\hline 4 & 4 & 3 & 1 \\
\hline 5 & 2 & 4 & -2 \\
\hline 6 & 4 & 3 & 1 \\
\hline 7 & 3 & 1 & 2 \\
\hline Totals & 25 & 22 & 3 \\
\hline Averages & 3.6 & 3.1 & 0.5 \\
\hline
\end{tabular}

\begin{tabular}{|c|c|c|c|}
$\begin{array}{l}\text { Unsuccessful } \\
\text { Cases }\end{array}$ & $\begin{array}{l}\text { Recorded } \\
\text { Information }\end{array}$ & $\begin{array}{l}\text { Conveyed } \\
\text { Information }\end{array}$ & Differences \\
\hline $1 \mathrm{a}$ & 4 & 3 & 1 \\
\hline $2 \mathrm{a}$ & 3 & 2 & 1 \\
\hline $3 \mathrm{a}$ & 4 & 3 & 1 \\
\hline $4 \mathrm{a}$ & 3 & 2 & 1 \\
\hline $5 \mathrm{a}$ & 4 & 3 & 1 \\
\hline $6 \mathrm{a}$ & 3 & 2 & 1 \\
\hline $7 \mathrm{a}$ & 4 & 1 & 3 \\
\hline Totals & 25 & 16 & 9 \\
\hline Averages & 3.6 & 2.3 & 1.3 \\
\hline
\end{tabular}


APPENDIX $\mathbf{F}$ 
RECORDED INFORMATION: A TALLY OF DISCRETE FACTS

\begin{tabular}{|c|c|c|c|c|c|c|c|c|c|c|}
\hline & \multicolumn{5}{|c|}{ Positive Information } & \multicolumn{3}{|c|}{ Negative } & \multicolumn{2}{|c|}{ Information } \\
\hline Cases & a & b & c & $\mathrm{d}$ & Totals & $\mathbf{a}$ & b & c & $\mathrm{d}$ & Totals \\
\hline$\underset{1}{\text { Successful }}$ & 0 & 6 & 8 & 6 & 20 & 0 & 7 & 12 & 7 & 26 \\
\hline 2 & 0 & 5 & 5 & 6 & 16 & 0 & 1 & 27 & 6 & 34 \\
\hline 3 & 0 & 3 & 0 & 11 & 14 & 0 & 4 & 12 & 2 & 18 \\
\hline 4 & 0 & 3 & 11 & 14 & 28 & 0 & 1 & 23 & 8 & 32 \\
\hline 5 & 0 & 3 & 1 & 4 & 8 & 0 & 0 & 9 & 0 & 9 \\
\hline 6 & 0 & 6 & 10 & 13 & 29 & 0 & 6 & 19 & 12 & 37 \\
\hline 7 & 0 & 4 & 14 & 6 & 24 & 0 & 0 & 16 & 1 & 17 \\
\hline Totals & 0 & 30 & 49 & 60 & 139 & 0 & 19 & h118 & 36 & 173 \\
\hline Percentages & 0 & 22 & 35 & 43 & 100 & 0 & 11 & 68 & 21 & 100 \\
\hline $\begin{array}{l}\text { Unsuccessful } \\
\text { la }\end{array}$ & 0 & 4 & 3 & 13 & 20 & 0 & 2 & 28 & 10 & 40 \\
\hline $2 a$ & 0 & 2 & 0 & 3 & 5 & 0 & 0 & 10 & 4 & 14 \\
\hline $3 \mathbf{a}$ & 0 & 3 & 11 & 8 & 22 & 0 & 9 & 15 & 11 & 35 \\
\hline $4 a$ & 0 & 1 & 2 & 5 & 8 & 0 & 0 & 17 & 5 & 22 \\
\hline $5 a$ & 0 & 2 & 7 & 6 & 15 & 0 & 1 & 17 & 7 & 25 \\
\hline $6 a$ & 0 & 1 & 2 & 15 & 18 & 0 & 0 & 12 & 11 & 23 \\
\hline $.7 a$ & 0 & 2 & 0 & 8 & 10 & 0 & 2 & 9 & 9 & 20 \\
\hline Totals & 0 & 15 & 25 & 58 & 98 & 0 & 14 & 208 & 57 & 179 \\
\hline Percentages & 0 & 15 & 26 & 59 & 100 & 0 & 8 & 60 & 32 & 100 \\
\hline
\end{tabular}


APPENDIX G 
CONVEYED INFORMATION: A TALLY OF DISCRETE FACTS

Positive Information Negative Information

\begin{tabular}{|c|c|c|c|c|c|c|c|c|c|c|}
\hline Cases & $a$ & $b$ & $c$ & $\mathrm{~d}$ & Totals & $a$ & $\mathrm{~b}$ & C & $d$ & Totals \\
\hline$\underset{1}{\text { Successful }}$ & 0 & 1 & 1 & 0 & 2 & 0 & 1 & 0 & 2 & 3 \\
\hline 2 & 0 & 1 & 2 & 1 & 4 & 0 & 1 & 5 & 2 & 8 \\
\hline 3 & 0 & 1 & 1 & 0 & 2 & 0 & 1 & 1 & 1 & 3 \\
\hline 4 & 0 & 1 & 1 & 2 & 4 & 0 & 1 & 1 & 1 & 3 \\
\hline 5 & 0 & 1 & 1 & 1 & 3 & 0 & 1 & 0 & 1 & 2 \\
\hline 6 & 0 & 1 & 1 & 1 & 3 & 0 & 1 & 0 & 2 & 3 \\
\hline 7 & 1 & 0 & 0 & 0 & 1 & 1 & 0 & 0 & 0 & 1 \\
\hline Totals & 1 & 6 & 7 & 5 & 19 & 1 & 6 & 7 & 9 & 23 \\
\hline Percentages & 5 & 32 & 37 & 26 & 100 & 4 & 26 & 30 & 40 & 100 \\
\hline $\begin{array}{c}\text { Unsuccessful } \\
\text { la }\end{array}$ & 0 & 1 & 0 & 0 & 1 & 0 & 1 & 0 & 1 & 2 \\
\hline $2 a$ & 0 & 1 & 0 & 0 & 1 & 0 & 1 & 0 & 0 & 1 \\
\hline $3 a$ & 1 & 0 & 0 & 0 & 1 & 1 & 0 & 2 & 1 & 4 \\
\hline $4 a$ & 0 & 1 & 0 & 0 & 1 & 0 & 1 & 0 & 0 & 1 \\
\hline $5 a$ & 0 & 1 & 0 & 0 & 1 & 0 & 1 & 1 & 0 & 2 \\
\hline $6 a$ & 0 & 1 & 0 & 0 & 1 & 0 & 1 & 0 & 0 & 1 \\
\hline $7 a$ & 1 & 0 & 0 & 0 & 1 & 1 & 0 & 0 & 0 & 1 \\
\hline Totals & 2 & 5 & 0 & 0 & 7 & 2 & 5 & 3 & 2 & 12 \\
\hline Percentages & 29 & 71 & 0 & 0 & 100 & 9 & 45 & 27 & 19 & 100 \\
\hline
\end{tabular}

